\title{
AVALIAÇÃO DE PROGÊNIES DE IRMÃOS GERMANOS INTERPOPULACIONAIS OBTIDAS DE COMPOSTOS DE MILHO (Zea mays L.)
}

\section{FERNANDO AJUDARTE NETO}

Engenheiro Agrônomo

Orientador: JOÃO RUBENS ZINSLY

\footnotetext{
Dissertação apresentada à Escola Superior de Agricultura

"Luiz de Queiroz", da Universidade de São Paulo,

para obtenção do título de Mestre em Genética - Melhoramento de Plantas.
}

$P|R A C| C A B A$

Estado de São Paulo - Brasil

Maio - 1978 
. 1 .

A

minha esposa

$e$ aos nossos pais

OFEREÇO 
.ii.

BIOGRAFIA DO AUTOR

FERNANDO AJUDARTE NETO, fitho de Fernando Ajudarte Fitho e de Cely Apparecida Pires de Ajudarte, nasceu em Jundiai, São Paulo, aos cinco dias do mês de outubro de 1948. Em 1971, ingressou na Escola Superior de Agricultura "Luiz de Queiroz" em Piracicaba, São Paulo, obtendo o àiploma de Engenheiro Agrônomo em 19 de dezembro de 1974. Em marso de 1975, iniciou suas atividades profissionais como estagiário do Instituto de Genética da ESALQ/USP onde, em agosto do mesmo ano, ingressou como aluno regular no Curso de Pós-graduacão em Genética e Melhoramento de Plantas. 
.iii.

\section{AGRADECIMENTOS}

- Ao Prof. Dr. João Rubens Zinsly pela valiosa orientação, ensinamentos e amizade,

- Ao Prof. Dr. Ernesto Paterniani, Diretor do IGen.. P吕 la amizade e pelas facilidades concedidas,

- Aos docentes do IGen. da ESALQ/USP pela amizade, estímulo e ensinamentos ministrados,

- Aos funcionários do IGen. da ESALQ/USP pela valiosa colaboração prestada no transcorrer do curso de pós-graduação e durante a execução deste trabalho.

- Aos amigos do Curso de Pós-Graduação em Genética e Melhoramento de Plantas pelo companheirismo em todos os momentos,

- Ao Conselho Nacional de Pesquisas (CNPq) pela bolsa de estudos concedida durante todo o período do curso de pós-graduação e execução deste trabalho.

meus sinceros agradecimentos. 
Pāgina

1. RESUMO . . . . . . . . . . . . . . . . . . 01

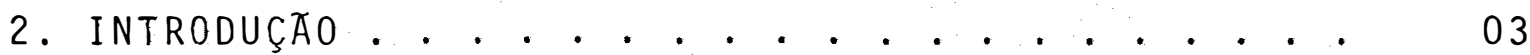

3. REVISÁO DA literatura. . . . . . . . . . . . . 07

3.1. 0 método do milho híbrido . ........ 07

3.2. 0 método dos híbridos duplos crípticos... . 11

4. MATERIAIS E METODOS. . . . . . . . . . . . 22

4.1. Caracterização dos materiais. . . . . . 22

4.2. Obtenção dos cruzamentos $S_{0} \times S_{0} . . . .224$

4.3. Ensaios de produção.......... . . 26

4.4. Obtenção dos dados. . . . . . . . . 27

4.5. Correção dos dados................. 29

4.6. Anālise estatística.................... 31

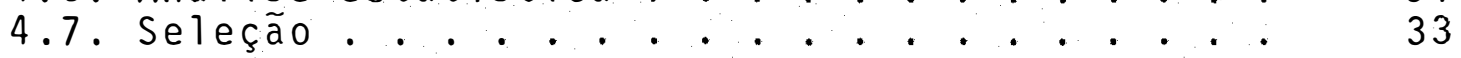

5. RESULTADOS OBTIDOS . . . . . . . . . . . . 34

5.1. Produção de grãos.............. 34

5.2. Indice de espigas por planta. . . . . . 41

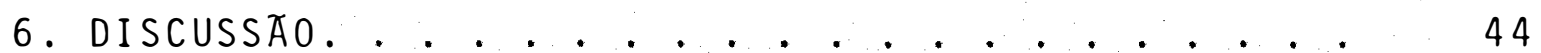

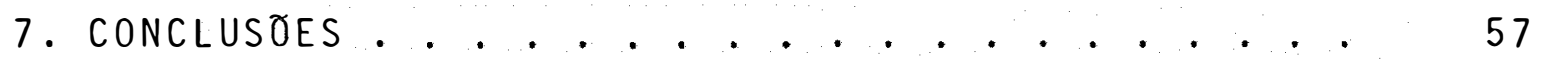

8. SUMmARY. . . . . . . . . . . . . . . 60

9. Literatura CitAdA. . . . . . . . . . . . 62

10. APENDICE . . . . . . . . . . . . . . . . 72

10.1. Tabelas...................... . . 72

10.2. Figuras............... . . . . 89 


\section{LISTA DE TABELAS}

$\underline{\text { Tabela }}$

Pāgina

01 - Análise da variância da produção de grãos em $\mathrm{kg} / 10 \mathrm{~m}^{2}$, corrigida para $15,5 \%$ de umidade, do experimento $I$, em látice simples duplicado $10 \times 10 . S_{0} \times S_{0}$. Piracicaba, 1975/76...

02 - Análise da variáncia da produção de grãos em $\mathrm{kg} / 10 \mathrm{~m}^{2}$, corrigida para $15,5 \%$ de umidade, do experimento II, em látice triplo $8 \times 8 . S_{0} \times S_{0}$. Piracicaba, $1975 / 76$. . . . . . . .

03 - Análise da variància da produção de grãos em $\mathrm{kg} / 10 \mathrm{~m}^{2}$, corrigida para $15,5 \%$ de umidade, do experimento III, em blocos ao acaso com duas repetições. $S_{0} \times S_{0}$. Piracicaba, 1975/76. .

04 - Análise da variancia para o caráter índice de espigas por planta, dos experimentos $I$, II e II , analisados como blocos ao acaso. $S_{0} \times S_{0}$.

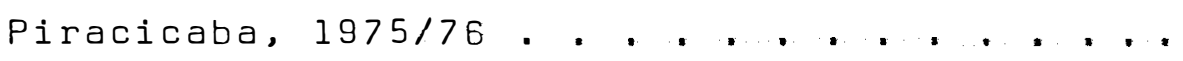

05 - Rendimento em grãos ( $\mathrm{kg} / \mathrm{ha}$ ) dos 95 cruzamentos $S_{0} \times S_{0}$ e das testemunhas, correspondentes ao experimento I, corrigidos para umidade de $15,5 \%$ e "stand" de 50 plantas por parcela. Produção em porcentagem da média das testemunhas $\mathrm{Ag}-152 \mathrm{R}$ e Centralmex. Valores médios do caráter índice de espigas por planta. Piracicaba, 1975/76. 
06 - Rendimento em grãos ( $\mathrm{kg} / \mathrm{ha}$ ) dos 59 cruzamentos $S_{0} \times S_{0}$ e das testemunhas, correspondentes ao experimento II, corrigidos para umidade de $15,5 \%$ e "stand" de 50 plantas por parcela. Produção em porcentagem da média das testemunhas $\mathrm{Ag}-152 \mathrm{R}$ e Centralmex. Valores médios do caräter índice de espigas por planta. Piracicaba, 1975/76.

07 - Rendimento em grãos ( $\mathrm{kg} / \mathrm{ha}$ ) dos 22 cruzamentos $S_{0} \times S_{0} e$ das testemunhas, correspondentes ao experimento III, corrigidos para umidade de $15,5 \%$ e "stand" de 50 plantas por parcela. Pro dução em porcentagem da média das testemunhas Ag-152 R e Centralmex. Valores médios do caráter índice de espigas por planta. Piracica-

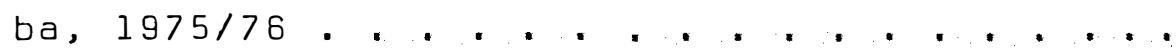

08 - Relação dos 70 cruzamentos $S_{0} \times S_{0}$ selecionados nos experimentos I, II e III. Peso de grãos em kg/ha, corrigidos para $15,5 \%$ de umida de e "stand" de 50 plantas por parcela. Porcen tagem da produção em relação à média das testemunhas Ag-152 R e Centralmex e o índice de espigas por planta. Piracicaba, 1975/76 . . . 


\section{LISTA DE FIGURAS}

Figura.

$\underline{\text { Pägina }}$

01 - Distribuição de frequências da produção de grãos, corrigidos para $15,5 \%$ de umidade,dos 95 híbridos crípticos correspondentes ao experimento $I$, expressa em \% das testemunhas (Ag-152 R e Centralmex). So $S_{0} S_{0}$. Piracicaba, 1975/76..

02 - Distribuição de frequências da produção de grãos, corrigidos para $15,5 \%$ de umidade,dos 59 híbridos crípticos correspondentes ao experimento II, expressa em \% das testemunhas (Ag-152 R e Centralmex). So $S_{0}$. Piracicaba, 1975/76..

03 - Distribuição de frequências da produção de grãos, corrigidos para $15,5 \%$ de umidade,dos 22 híbridos crípticos correspondentes ao experi mento III, expressa em \% das testemunhas ( $\mathrm{Ag}-152 \mathrm{R}$ e Centralmex). So $\times S_{0}$. Piracicaba, 1975/76..

04 - Distribuição de frequências da produção de grãos, corrigidos para $15,5 \%$ de umidade, dos 176 híbridos crípticos correspondentes aos três ex perimentos, expressa em \% das testemunhas(Ag-152R e Centralmex). $S_{0} \times S_{0}$. Piracicaba, 1975/76..

05 - Distribuição de frequèncias dos índices de espiga por planta dos 176 híbridos crípticos correspondentes aos três experimentos, transforma dos em $\sqrt{x}$. So $\times S_{0}$. Piracicaba, 1975/76. . 
viii.

Figura

Pägina

06 - Distribuição de frequéncias da porcentagem média de plantas acamadas (acamadas + quebradas) por tratamento (P), dos 176 híbridos crípti cos correspondentes aos trés experimentos, transformados em arc sen $\sqrt{\mathrm{P} / 100}$. So $\times S_{0}$. Piracicaba, $1975 / 76 . . . . . . . . .$. 


\section{RESUMO}

Foi avaliado, pelo presente trabalho,o comporta mento concernente à produção de grãos e ao índice de espigas por planta, de 176 progênies de irmãos germanos $S_{0} \times S_{0}$ (híbridos duplos cripticosl obtidas pelo intercruzamento dos Compostos "Flint" e "Dentado", correspondendo à fase inicial do método pró posto por HALLAUER (1967a) e LONNQUIST e WILLIAMS (1967). Os Compostos"Flint" e "Dentado", sintetizados no Instituto de Ge nética da ESALQ/USP, são bastante prolíficos,possuem ampla variabilidade genética e alta produtividade e se encontravam,por ocasião das autofecundações e cruzamentos, em avançadas gerações de seleção entre e dentro de famílias de meios-irmãos.

Os 176 cruzamentos foram testados em ensaios de produção, juntamente com 5 testemunhas, entre as quais o híbri do duplo $\mathrm{Ag}-152 \mathrm{R}$ e a variedade Centralmex. Foram extrapolados os valores de produção de grãos para os compostos paternais, haja visto que os mesmos não foram incluídos nos ensaios.

Dos resultados obtidos, por este trabalho, pode-se tirar as seguintes conclusões: 
- A heterose obtida, sugere que os dois compostos paternais são boas fontes de obtenção de linhagens, pelo mé todo proposto.

- A obtenção de cruzamentos $S_{0} \times S_{0}$ mais produtivos que o híbrido e variedade controles, comprovam a eficiência do método para identificar cruzamentos especificos superio res, obtidos entre populações previamente melhoradas e, o elevado rendimento de alguns cruzamentos, na primeira etapa do mé todo, mostram uma redução no tempo requerido para a obtenção de híbridos de milho.

- o método é eficiente para o aumento de prolificidade, haja visto o aumento verificada no indice de espigas por planta, correspondente ao aumento da produção. Baixas intensidades de seleção, aplicadas na primeira etapa do método, possibilitam a manutenção de uma maior variabilidade genética para permitir a continuidade do método.

- A utilização de somente uma espiga, dentro de cada par de plantas, para o cruzamento entre as mesmas, é suficiente para a avaliação preliminar dos híbridos crípticos assim obtidos.

- A liberação da variabilidade genética é mais rápí da pelo uso de progênies de irmãos germanos interpopulacionais, quan do comparada ao uso de progênies de meios-irmãos intrapopulacionais, nas duas populações em questão.

- o uso de um esquema de seleção recorrente recípro ca em famílias de irmãos germanos possibilitaria o aumento da hete rose entre os compostos "Flint" e "Dentado". 


\section{INTRODUÇÃO}

A sugestão para o melhoramento prévio de populações de milho (LONNQUIST, 1951, 1961 e PATERNIANI, 1966, 1969), objetivando a utilização das mesmas como variedades sintéticas ou como fonte de linhagens superiores, é de origem bastante re cente. A partir da década de cincoenta, como consequência da evolução dos conhecimentos sobre a situação genética da produtividade do milho e, em particular, de uma compreensão das variàncias genéticas em disponibilidade nessa espécie, é que essa situação tem evoluido continuamente.

Não obstante sua larga difusão, o método do miIho híbrido, favorecido nas últimas décadas pela bem sucedida utilização dos métodos de melhoramento de populações, que permitem uma maior eficiência na extração de linhagens superiores, tem no entanto ainda hoje, encontrado, em sua utilização, vários problemas, entre os quais:

- o tempo, relativamente longo, dispendido com 
a obtenção das linhagens por meio, geralmente, do tradicional método "standard".

- A seleção, inteiramente casual no tocante à produção de grãos, efetuada entre e dentro das linhagens durante as várias gerações de autofecundação, uma vez que é baseada unicamente em atributos agronômicos.

- A capacidade combinatória das linhagens obtidas é completamente desconhecida até que o processo de endogamia se complete.

- Os testes para a capacidade combinatória, assim como a seleção neles baseada, demandam um maior número de gerações e, obviamente, despe sas adicionais.

Recentemente, HALLAUER (1967a, 1967b) e LONNQUIST e WILLIAMS (1967) sugeriram modificações ao método do milho híbrido, com o intuito de eliminar as desvantagens apresentadas pelo método "standard" de obtenção de linhagens. o procedimento permite, teoricamente, a obtenção de híbridos simples em curto período de tempo e, suas módificações residem principalmente na utilização, como material básico, de populações de plantas prolificas (plantas com duas ou mais espigas).

o método é baseado no comportamento de progênies de irmãos germanos interpopulacionais, denominados "Hí- 
bridos duplos crípticos", obtidos pelo cruzamento entre populações melhoradas de milho. O método requer, para sua aplicação, populações de plantas prolíficas pois, são realizados cru zamentos e autofecundações simultaneamente em uma mesma planta, utilizando-se portanto, de duas de suas espigas, a primeira (superior) destinada ao cruzamento e a segunda (inferior) à autofecundação. A avaliação para capacidade específica de com binação pode ser feita à cada geração de intercruzamento, pelo isolamento de progénies de irmãos germanos. Ao final do programa obtêm-se linhagens endogámicas com alta capacidade de combinação para a síntese de híbridos simples, duplos ou triplos. O método permite portanto, uma substancial redução no tempo requerido para a obtenção de linhagens para a produção de híbridos de milho.

Este trabalho, desenvolvido no Instituto de Genética da Escola Superior de Agricultura "Luiz de Queiroz", em Piracicaba, Estado de São Paulo, tem por objetivos:

- Testar a viabilidade do método dos híbridos crípticos em nossas condições, uma vez que trä ta-se de um método de grande importáncia na atualidade, utilizando-se, para tanto,de duas populações prolíficas bem adaptadas, o Compos to Dentado e o Composto "Flint", ambos sintetizados no Instituto de Genética da ESALQ/USP. 
.06.

- Avaliar o comportamento das populações citadas, como germoplasma básico para a obtenção de linhagens, pelo método mencionado. 


\section{REVISÁO DA LITERATURA}

3.1. 0 método do milho hỉbrido

Inúmeras revisões detalhadas sobre as diferentes etapas da evolução dos métodos de melhoramento de milho, particularmente do método do milho híbrido, já foram realizadas por vários autores (SPRAGUE, 1955; PATERNIANI, 1966; MAGNAVACA, 1973; LOPES, 1974). Por esta razão procuraremos tão sómente citar os principais eventos que determinaram o advento e desenvolvimento do método do milho híbrido, deixando de nos detalhar em relação aos mesmos.

Os primeiros estudos sobre autofecundação em mi Iho, provavelmente realizados por Darwin em 1877 (SPRAGUE, 1955), seguidos dos trabalhos de BEAL (1877) e de MORROW e GARDNER (1893) referentes à hibridações intervarietais, que evidenciaram a ocorréncia de heterose para rendimento de grãos em miIho, estimularam a realização de estudos posteriores como os de SHULL (1908, 1909) e os de EAST (1908, 1909), com endogamia 
e cruzamentos, que vieram à culminar com o advento do método do milho híbrido.

A princípio, algumas dificuldades surgiram no tocante à aplicação prática do método. Essas dificuldades foram então sanadas pela sugestão de JONES (1918), para a utilização do híbrido duplo e pelos estudos de JENKINS (1934), DoXTATOR e JOHNSON (1936) e ANDERSON (1938) por intermédio do método de previsão do híbrido duplo.

Os programas de melhoramento, visando a obtenção de híbridos de linhagens, envolvem geralmente, três etapas distintas (RICHEY, 1950 ):

- Obtenção, por meio de autofecundação e seleção, de linhagens melhoradas para certas características agronómicas de interesse.

- Identificação das linhagens mais satisfatórias para determinados propósitos.

- Utilização prática das linhagens selecionadas em alguns tipos de híbridos.

Inúmeros métodos têm '́sido propostos e utilizados para a obtenção e avaliação de linhagens puras, objetivando aumentar a eficiência do método do milho híbrido. Várias re visões detalhadas foram, também, realizadas sobre o assunto por RICHEY (1950), SPRAgUe (1955), JUGENHÉIMER (1958) e PATER- 
NIANI (1966). Nessas revisões os seguintes métodos são citados: Método "standard", Melhoramento convergente e retrocruzamento (RICHEY, 1927), Método da cova simples (JONES e SINGLETON, 1934), Seleção por "pedigree" (HAYES e JOHNSON, 1939 e JOHNSON e HAYES, 1940); Seleção gamética (STADLER, 1944), Diplóides homozigóticos (CHASE, 1949) e suas modificações, propos tas por BURNHAM (1946) e pelo próprio autor do método (CHASE, 1952); Teste precoce (SPRAGUE, 1946 e LONNQUIST, 1950).

o método "standard" é, dentre todos, o mais uti lizado. Por esse tradicional método, as linhagens, de uma maneira geral, são obtidas pela seleção das plantas que apresentam as melhores características agronómicas. São realizadas de 3 à 4 autofecundações sucessivas e a seleção é praticada à cada geração, entre e dentro das progẽnies de autofecundação, eliminando-se as plantas com características agronómicas inferiores. As linhagens $\mathrm{S}_{3}$ ou $\mathrm{S}_{4}$ obtidas, são então testadas para capacidade geral de combinação e posteriormente, para capacidade específica de combinação. Pela descrição do método,constata-se que o tempo dispendido na obtenção e avaliação das linhagens é longo e dispendioso, que a seleção é feita somente com base em características agronómicas tornando casual o desenvolvimento de linhagens no tocantè à produção e, finalmente, que somente possibilita o conhecimento da capacidade combi natória das linhagens ao final do programa. 
obtidas por um procedimento qualquer são também de grande importáncia. O valor dessas linhagens é revelado pela sua capacidade geral de combinação, que indica os efeitos aditivos dos genes e, pela capacidade específica de combinação, que reflete os efeitos gênicos não aditivos tal como os efeitos dominantes e epistáticos dos genes. A capacidade geral e específica de combinação foram conceituadas por SPRAGUE e TATUM (1942).

PATERNIANI ( 1969 ) tecendo considerações sobre o método do milho híbrido comenta que, depois de 1930, os novos híbridos obtidos eram relativamente pouco superiores aos já existentes, muito embora a soma de esforços dispendidos fosse bem maior que quando da obtenção dos primeiros híbridos. o melhoramento de populações à serem utilizadas como material bási co para a extração de novas linhagens, superiores às já existentes, foi então sugerido por LONNQUIST (1949, 1951, 1961) e PATERNIANI (1966, 1969).

Existem vários métodos que foram idealizados com - intuito de se promover o melhoramento de populações à serem utilizadas como fonte de linhagens endogámicas para produção de híbridos. Vários esquemas utilizados, com o objetivo de aumentar a frequência de genes superiores em populações, são citados em PATERNIANI (1966, 1969).

A grande variabilidade existente em diferentes raças e variedades de milho, passou à ser melhor aproveitada com a introdução de métodos de formação de compostos. Esses com 
postos, representando vários tipos de milho existentes, ofere cem uma maior oportunidade de seleção de vários atributos de interesse agronômico (CASTRO, GARDNER e LONNQUIST, 1968 e PATERNIANI, 1968). "A partir daí, novos métodos surgiram, como consequéncia do melhoramento de populações, objetivando, não só incrementar a eficiência na obtenção de linhagens e híbridos, como também minimizar o tempo dispendido em sua obtenção.

Dentre outros, um método que pode ser iniciado à partir da síntese de dois compostos portadores de suficiente variabilidade genética e, que quando cruzados entre si, mostrem heterose, foi proposto por EBERHART, HARRISON e OGADA (1967). Este método, sëgundo LONNQUIST e WILLIAMS (1967), pode ser uti lizado efetivamente na redução do tempo requerido no desenvolvimento de híbridos superiores. A seleção para capacidade específica de combinação pode, por esse procedimento, ser feita à cada geração de intercruzamentos das duas populações, por meio do isolamento de famílias de irmãos germanos, denominados "Híbridos Duplos Crípticos".

\subsection{O método dos híbridos duplos crípticos}

A denominação de "híbridos duplos crípticos", aplicada às famílias de irmãos germanos interpopulacionais por LONNQUIST e WILLIAMS (1967), é devida ao fato de que, sendo uma planta de uma população qualquer, provavelmente heterozigota 
em um grande número de loci e, portanto, produto da união de dois gametas diferentes, pode-se imaginar duas linhagens homozigóticas que, produzindo esses dois gametas, reconstituiriam a referida planta. Essa seria, portanto, um híbrido simples, oriundo do cruzamento entre duas linhagens que o melhorista ainda não tem e que, portanto, são linhagens ocultas ou "crípticas". Cruzando-se plantas de duas populações diferentes, as quais se consideram híbridos simples crípticos, obtem-se um híbrido duplo críptico, segundo descrição feita por MAGNAVACA $(1973)$.

Baseado nestes princípios, um método que tem por finalidade selecionar os melhores pares de linhagens puras, du rante o processo de endogamia das mesmas, foi sugerido por HALLAUER (1967a, 1967b) e LONNQUIST e WILLIAMS (1967). Existem pequenas diferenças entre a metodologia utilizada por es ses autores, mas é um método que possibilita maximizar a seleção entre pares de genótipos, com base na sua performance de rendimento, em combinações hỉbridas, utilizando-se para tanto de plantas prolíficas. Este método difere da maioria dos méto dos tradicionais de melhoramento pois são selecionados, em cada geração de endogamia, pares de genótipos ao invés de genótipos individuais. A metodologia utilizada por HÁLLAUER (1967a), já acrescida das modificações utilizadas por LONNQUIST e WILLIAMS (1967) é descrita a seguir.

FASE I - São reạlizadas autofecundações em plan tas individuais $s_{0}$ nas duas populações, utilizando-se,para tan 
to, das espigas inferiores. As autofecundações são efetuadas afim de se manter o genótipo das plantas para a próxima etapa. Cerca de dois à três dias depois são realizados os cruzamentos entre as plantas individuais $S_{0}$ já autofecundadas, das duas populações, utilizando-se, desta feita, das espigás superiores. Os híbridos $S_{0} \times S_{0}$ produzidos, são avaliados em ensaios de produção e, as sementes oriundas da autofecundação de cada planta So, são armazenadas para a etapa seguinte. Uma intensi dade média de seleção, de 30 à $50 \%$, é sugerida, caso os cruzamentos não possam ser testados rigorosamente pela insuficiència de sementes.

FASE I I - Os pares de linhagens $S_{1}$, correspondentes ao cruzamento $S_{0} \times S_{0}$, selecionados na primeira fase, são plantados pareados pelo esquema espiga-por-fileira. Repete-se então, entre as plantas dos pares de progennies $S_{1}$, o mes mo procedimento utilizado em So para os cruzamentos e autofecundações. Sugere-se que, de 4 à 6 cruzamentos sejam feitos dentro de cada par de progénies $S_{1}$. Da mesma forma anterior, as progênies, agora $S_{1} \times S_{1}$, são avaliadas em ensaios de produção. Sugere-se, também aqui, uma seleção de intensidade média, ou seja, de 30 à $50 \%$.

FASE III - As sementes $S_{2}$, do material selecionado, são plantadas, espiga-por-fileira, em pares que correspondem aos cruzamentos So $x$ So iniciais. Cruzam-se e auto- 
fecundam-se as plantas $S_{2}$. Da mesma forma anterior, os cruzamentos $S_{2} \times S_{2}$ são avaliados em ensaios de produção e nova seleção é realizada para dar continuidade aos cruzamentos e auto fecundações entre as plantas das progênies $\mathrm{S}_{3}$.

FASE n - o processo é repetido até que as progènies autofecundadas selecionadas até o momento atinjam um bom nível de homozigose e homogeneidade.

o interesse principal do método sugerido por HALLAUER (1967a, 1967b)", reside na performance das combinações específicas pois, a seleção é feita entre os pares de genótipos. As avaliações, inicial e subsequente, são feitas para es sas combinações específicas, possibilitando assim, uma maximização da seleção para os efeitos genéticos não aditivos e aumentando, também, a eficiência no desenvolvimento de híbridos simples.

Uma eficiente aplicação prática dessa metodologia é relatada por HALLAUER (1967a, 1967b, 1973). Em seus tra balhos, visando a obtenção de híbridos crípticos, utilizou-se de duas populações prolíficas: o Composto "Pioneer" ("Pioneer Two-ear-Composite") e o Sintético "Iowa" ("Iowa Two-ear-Synthetic"). obteve primeiramente, 144 progénies $S_{0} \times S_{0}$ e os pares de sementes correspondentes $S_{1}$ à cada cruzamento. As progênies

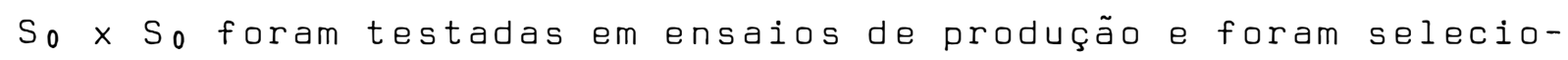
nados, à partir daí, os 54 melhores cruzamentos. Nessa fase, 
somente 2 cruzamentos apresentaram rendimentos superiores à mé dia dos híbridos controles. O método, na geração $S_{5}$, teve todos os 14 híbridos selecionados excedendo a média dos controles. O método prosseguiu até a geração $S_{6}$ onde somente 5 das progênies representativas das plantas $S_{0}$ originais, foram incluídas nos 14 híbridos que, conforme já citado, foram superio res à média dos híbridos controle.

LONNQUIST e WILLIAMS (1967) relatam os resultados obtidos com a aplicação do método, como originalmente proposto, empregando as populações SSSIII e B IV. que se encontravam nos ciclos III e IV, respectivamente, de seleção recorrente para capacidade geral de combinação. Foram obtidas 102 pro gènies de irmãos germanos, híbridos crípticos, $S_{0} \times S_{0}$ que foram avaliadas em ensaios de produção. Observou-se uma heterose média de $31 \%$, variando de $-8 \%$ à $51 \%$, o que revela uma grande variação entre as 102 progénies. a rendimento médio dos cruzamentos $S_{0} \times S_{0}$ foi $6 \%$ maior que a média dos híbridos testemunhas. Foram selecionados os 5 melhores cruzamentos $S_{0} \times S_{0}$ e, à partir desses, obtidos cruzamentos $S_{1} \times S_{1}$ que foram tes tados em ensaios de produção. Não houve diferenças significativas entre o rendimento dos $S_{1} \times S_{1}$, quando comparados com os $S_{0} \times S_{0}$. Diferenças significativas foram observadas entre cru zamentos dentro de cada família.

Em nosso meio, SILVA (1970) utilizou-se do méto do dos híbridos crípticos, descrito por LONNQUIST e WILLIAMS 
(1967), empregando as populações Cateto PG e Azteca PG, anteriormente selecionadas para prolificidade e produtividade; as populações MAYA V e IAC-l IV, selecionadas para produção e; a população WP-12, não melhorada. Apesar do reduzido nümero de cruzamentos, onde Cateto PG x Azteca PG apresentou o maior número, ou seja, 54 cruzamentos, foram constatados expressivos ganhos genéticos em quase todos os grupos de cruzamentos individuais. Foi também observada, pelo autor, uma tendência gene ralizada para uma maior produtividade quando o índice de espigas é elevado. Alguns cruzamentos específicos chegaram à exce der em 40 à $50 \%$ às testemunhas, em rendimento de grãos. Como testemunha foi utilizado o híbrido intervarietal MAYA IV $x$ IAC III.

MAGNAVACA (1973) realizou um programa de melhoramento de milho, no Estado de Minas Gerais, aplicando o pro cesso de obtenção de linhagens extraído do método dos híbridos crípticos proposto por HALLAUER (1967a) e LONNQUIST e WILLIAMS (1967). Utilizou-se de duas populações de ampla base genética, denominadas Cateto Colómbia Composto e Dentado Composto A. Foram obtidos 104 cruzamentos $S_{0} \times S_{0}$ que foram testados em ensaios de produção. Selecionou-se 39 dos 104 híbridos crípticos, o que corresponde à uma intensidade de seleção de $37,5 \%$. Em uma sejgunda fase, o material selecionado deu órigem à 89 progênies $S_{1} \times S_{1}$ que foram testadas em ensaios de produção. Selecionou-se então, 33 dos 89 híbridos crípticos, o que corresponde à uma intensidade de seleção de $37,2 \%$. Esses cruzamentos selecionados correspondem à $24 \%$ das famílias de irmãos ger 
manos $S_{0} \times S_{0}$, avaliados inicialmente pois, dos 39 cruzamentos selecionados, 25 forneceram progénies $S_{1} \times S_{1}$ que foram utilizadas para o prosseguimento do programa. 0 autor encontrou alta heterose em cruzamentos específicos de progênies $S_{0}$. Alguns híbridos $S_{1} \times S_{1}$ foram superiores à produção dos melhores híbridos da região de Sete Lagoas, Minas Gerais.

Um outro estudo, no qual foi utilizado o método dos híbridos crípticos, é relatado por LOPES (1974). Nesse tra balho, correspondente à fase inicial do método, efetuou-se a avaliação do comportamento de progênies $S_{0} \times S_{0}$, obtidas de cru zamento entre os Compostos "A" e "B", prolíficos, sintetizados no Instituto de Genética da ESALQ/USP, em Piracicaba, São Paulo. Um total de 173 progênies foil obtido e, essas progênies foram testadas em ensaios de produção. Verificou-se uma heterose de $5,14 \%$ em relação à média dos pais. Selecionou-se 69 cruzamentos $s_{0} \times S_{0}$ mais produtivos e observou-se uma heterose de $19,23 \%$ em relação à média dos pais. Isto sugere que os Compostos "A" e "B", constituem-se em boas fontes para a obtenção de linhagens. Foi constatado também que, entre os 173 híbridos crípticos tes tados, 78 deles mostraram-se superiores, no que diz respeito ao rendimento, às testemunhas híbrido duplo Ag-152 R e a varie dade Centralmex.

Vale ser salientado que, as fases do método dos híbridos crípticos não são, necessariamente, feitas em períodos agrícolas distintos. Os cruzamentos e autofecundações fei 
.18.

tas na geração $S_{\mathfrak{l}}$, podem ser realizadas simultaneamente à avaliação das progénies $S_{0} \times S_{0}$, com a desvantagem porém, de que somente 30 à $50 \%$ dessas autofecundações e cruzamentos seräo aproveitados.

0 método da seleção recorrente recíproca em pro gênies de irmãos germanos, sugerido por HALLAUER e EBERHART (1970), tem alguma semelhança com o método dos híbridos crípti cos. Enquanto que no último, a seleção aumenta a frequência dos genes complementares nas duas populações, incrementando a capacidade específica de combinação, o método proposto por HALLAUER e EBERHART (1970) objetiva, por meio da seleção, aumentar a frequéncia de genes que contribuem para a variáncia aditiva, explorando portanto: a capacidade geral de combinação. Essa metodologia, ou seja, seleção recorrente recíproca em familias de irmãos germanos, foi utilizada, mais recentemen te, por MORo et alii (1974). Através de ensaios de 297 famílias $S_{0} \times S_{0}$, obtidas de duas populações sintetizadas no Insti tuto de Genética da ESALq/USP,os Compostos "A" e "B", os autores verificaram que a média dos tratamentos ensaiados, foi superior à média das testemunhas, em"todos os experimentos realizados.

Embora os resultados e aspectos aqui mencionados forneçam fortes evidéncias da capacidade do método, em detectar e aproveitar efeitos genéticos altamente específicos, um estudo realizado recentemente por ZINSLY (1977), que teve 
por objetivos avaliar as possibilidades da obtenção de híbridos comerciais, para as condições brasileiras, à partir do método proposto por LONNQUIST e WILLIAMS (1967) e HALLAJER (1967a), em dois compostos sintetizados no Instituto de Genética da ESALQ/USP, mostraram os seguintes resultados, baseados em ensaios de produção, no sucesso da obtenção de cruzamentos e no comportamento das linhagens:

- Das plantas $S_{0}$ que deram híbridos superiores, não se obtiveram linhagens consideradas comer ciais.

- A consanguinidade $(F=0,50)$, diminuiu a prolificidade das plantas, comprometendo a continuidade do método.

- Os melhores híbridos $S_{1} \times S_{1}$ suplantaram, em peso de grãos, os cultivares Centralmex e Ag-152R, porém foram inferiores no tocante à susceptibilidade ao acamamento e porte das plantas.

- o método, como originalmente proposto, não é viável entre as populações disponíveis no nos so país. Assim, foram sugeridas algumas modi ficações ao método, esperando que o mesmo,des sa forma, possa ser aproveitado em nossas con dições. 
o método dos híbridos crípticos exige, para sua aplicação, plantas prolíficas em pelo menos uma das populações paternais. Descrevendo o método da seleção recorrente no desenvolvimento de variedades sintéticas, JENKINS (1940) sugeriu, quando a população paternal é prolífica, o uso de uma espiga para autofecundação e da outra para cruzamentos. Alguns estudos preliminares já haviam, "no entanto, sido realizados, por meio de polinizações duplas para produzir sementes autofecundadas e cruzadas na mesma planta. Assim, sementes autofecundadas e cruzadas foram obtidas por SPRAGUE (1939) e WILLIAMS et alii $(1965)$.

Não só a existência inicial do caráter prolificidade é importante. A manutenção do caráter, durante o desen volvimento do método é essencial ao sucesso do mesmo. Populações de plantas prolíficas apresentam também, melhores resulta dos quanto à produção de grãos. Vários estudos realizados, tal como os de FREEMAN (1955), JOSEPHSON (1957, 1961) e COLLINS et alii (1965), indicam a maior produtividade dos milhos prolíficos em relação aos milhos não específicos. BAUMAN (1960) de monstrou que, em média, $25 \%$ da produção total foi fornecida pe las espigas secundárias. LONNQUIST (1967) em trabalho clássico, obteve acréscimos de $6,28 \%$ no rendimento de grãos, por ciclo de seleção massal para produtividade, em 5 ciclos. Finalmente, resultados apresentados por HALLAUER (1973) demonstram a importância da capacidade de produção de sementes da espiga secundária, no desenvolvimento de híbridos de rendimento supe- 
.21.

rior. Cerca de $31 \%$ da produção de grãos, de 14 híbridos simples selecionados, foi fornecida pelas espigas inferiores ou secundárias. 


\section{MATERIAIS E METODOS}

\subsection{Caracterização dos materiais}

Os materiais utilizados no presente trabalho, são oriundos de populações de milho, formadas em grande parte à partir de amostras do Programa Agrícola Mexicano da Fundação Rockefeller. Essas populações, denominadas Composto "Dentado" e Composto "Flint", foram sintetizadas no Instituto de Genética da ESALQ/USP, em Piracicaba, Estado de São Paulo,e en contravam-se, por ocasião das autofecundações e cruzamentos, em gerações adiantadas de recombinação e de seleção entre e den tro de familias de meios-irmãos. Os compostos "Dentado" e "Flint" além de prolíficos, condição esta necessária à aplicação do método, possuem grande variabilidade genética. Vale-se salientar que, os chamados "Compostos", têm recebido, ultimamente, grande atenção por parte dos melhoristas, quando da pla nificação e execução de seus programas de melhoramento.

o Composto "Dentado" foi obtido à partir de cru 
zamentos entre milhos brancos e amarelos, representativos de germoplasmas do México, América Central e América do Sul, enquanto que o Composto "Flint", foi obtido pelo cruzamento entre milhos brancos e amarelos, de endosperma do tipo duro ("Flint"), representativos de germoplasmas originados principalmente da América Central, Colómbia e Brasil. Uma breve des crição das amostras de milho utilizadas na formação desses dois compostos pode ser encontrada em PATERNIANI (.2968).

A metodologia seguida na síntese dos dois compostos, ou seja, os Compostos "Flint" e "Dentado", pode ser, resumidamente, assim descrita: Os tipos de milho com grande diversidade genética e com características apropriadas foram intercruzados, garantindo as'sim, uma efetiva participação dos mesmos. Os compostos, assim obtidos, foram submetidos à recom binação por trés gerações de polinização aberta, praticando-se à seguir um ciclo de seleção massal e, posteriormente, três ciclos de seleção entre e dentro de famílias de meios-irmãos pa ra o aumento de produtividade. A finalidade desses compostos, segundo PATERNIANI (1968), é a de essencialmente melhor se aproveitar a variabilidade genética existente nas raças e variedades. Ainda recentemente, os Compostos "Flint" e "Dentado" passaram à receber as denominações de ESALQ VF-2 é ESALQ VD-I, respectivamente (PATERNIANI et alii, 1977).

Como testemunhas foram utilizados: 0 híbrido duㅡ plo Ag-152R, com grãos de aparéncia semi-dentada e de colora- 
ção amarela. O híbrido duplo Ag-152 R, produzido pela Sementes Agroceres S.A., é de grande aceitação comercial na região de Piracicaba; a variedade Centralmex, sintetizada no Instituto de Genética da ESALQ/USP, também de grande aceitação comer cial; o Composto "A"; o Composto "B" e a sétima geração de intercruzamentos entre esses dois últimos compostos $\left(F_{7}\right)$. Os Com postos "A" e "B" também foram sintetizados no Instituto de Genética da ESALQ/USP, à partir de lo populações do Banco de Ger moplasmas desse Instituto. Uma breve descrição dessas duas po pulações pode ser encontrada em PATERNIANI (1968).

\subsection{Obtenção dos cruzamentos $S_{0} \times S_{0}$}

As sementes foram semeadas em linhas alternadas, ou seja, de maneira tal, que à cada linha semeada com o Composto "Flint", seguia-se uma outra semeada com o Composto "Dentado" e, assim sucessivamente, com a finalidade de serem facilitados os cruzamentos entre as plantas dos dois compostos.

Por ocasião do florescimento, uma seleção visual de plantas com características agronōmicas favoráveis, foi realizada no Composto "Dentado". Simultaneamente, a segunda espiga (espiga inferior) de cada planta foi autofecundada. Na mesma época, as mesmas operações foram levadas a termo no Composto "Flint" sendo que, as autofecundações em ambos os compos 
tos, foram realizadas afim de se préservar os genótipos: das plantas.

Cerca de dois dias após àquelas operações, a es piga superior (primeira espiga) de cada planta, anteriormente autofecundada, dos dois compostos, foram polinizadas de maneira que, cada planta selecionada do Composto "Flint" foi,manual mente, polinizada pelo pólen de uma planta do Composto "Dentado", igualmente selecionada e localizada na linha adjacente. Assim realizados os cruzamentos, procedeu-se à identificação dos mesmos juntamente com as respectivas autofecundações. Foram realizadas 1.000 autofecundações em cada um dos compostos obtendo-se, simultaneamente, I.000 cruzamentos.

De acordo com LONNQUIST e WILLIAMS (1967), para que se pudesse evitar a ocorrência da dominância apical, que impede o desenvolvimento da segunda espiga (inferior) quando a primeira espiga (superior) é primeiramente fertilizada,os cru zamentos na espiga superior de cada planta, foram realizados 2 dias após terem sido procedidas as autofecundações nas espigas inferiores dessas mesmas plantas.

Uma nova seleção visual foi realizada após a cọ Iheita desta feita nas espigas, com a finalidade de se eliminar aquelas com características indesejáveis, bem como aquelas representantes de autofecundações e de cruzamentos que se apre sentaram com insuficiente quantidade de sementes $S_{1}$ ou $S_{0} \times S_{0}$, respectivamente, necessárias ao prosseguimento do método em ge 
rações futuras. Dessa forma foram obtidos 176 cruzamentos com os respectivos pares de sementes remanescentes $S_{1}$.

\subsection{Ensaios de produção}

A avaliação das 176 progēnies de irmãos-germanos $S_{0} \times S_{0}$ foi realizada, obedecendo-se aos delineamentos descritos à seguir:

Experimento I - Em látice simples duplicado $10 \times 10$ ( 4 "repetições). 0 experimento I constou de 95 progênies de irmãos-germanos $S_{0} \times S_{0}$. E, como testemunhas, do Composto "A", do Composto "B", da geração F, do cruzamentos entre es ses dois compostos, do Ag-152 R e da variedade Centralmex tota lizando, dessa forma, 100 tratamentos.

Experimento II - Em látice triplo 8 × 8 (3 repetições). O experimento I I constou de 59 progênies de irmãos-germanos $S_{0} \times S_{0}$ e das mesmas testemunhas do experimento $I$, to talizando 64 tratamentos.

Experimento III - Em blocos casualizados com duas repetições. O experimento III incluiu as 22 progènies de irmãos-germanos $S_{0} \times S_{0}$ restantes e das mesmas testemunhas já citadas totalizando 27 tratamentos.

Em ensaios foram realizados em uma ärea cedida 
ao Instituto de Genética da ESALQ/USP, localizada no Bairro de Agua Santa, Município de Piracicaba, Estado de São Paulo, à uma altitude de 556 metros e latitude de $22^{\circ} 43^{\prime}$. Os ensaios foram instalados entre os dias 15 e 31 de outubro de 1975.

O espaçamento adotado foi de 0,40 metros entre covas e de l,00 metro entre linhas. Foram estabelecidas assim, 25 covas por parcela de 10 metros e semeados 3 grãos por cova, totalizando 75 sementes por parcela.

o desbaste, procurando-se manter 2 plantas por cova, foi efetuado 15 dias após o plantio pois, segundo VIEGAS (1966), o desbaste, quando efetuado nesse estágio do desenvolvimento das plantas, não chega à ocasionar prejuizos sérios à produção. Assim, o "stand" inicial de 75 plantas por parcela, foi reduzido para um "stand" de 50 plantas por parcela (2 plan tas por cova), o que corresponde à uma densidade populacional de 50.000 plantas por hectare. Os 3 experimentos totalizaram, portanto, 646 parcelas, além de 3 linhas plantadas ao redor dos ensaios, como bordadura, com a variedade Centralmex.

\subsection{Obtenção dos dados}

Imediatamente após o completo desenvolvimento vegetativo das plantas, procedeu-se à anotação dos dados referentes às características das mesmas, em condições de campo. 
Assim, foram coletados dados referentes à:

- "Stand" final - Antes da colheita foi anotado o "stand" final para todos os tratamentos, ou seja, o nümero de plantas por parcela na ocasião da colneita, assim como foi anotado o número de plantas acamadas e quebradas, em porcentagem com relação ao "stand" final.

Indice de espigas por planta - Foi realizada uma contagem do número de espigas por parcela, em cada um dos tratamentos, nos 3 experimentos. o total de espigas por parcela foi dividido pelo correspondente "stand" dessa parcela, obtendo-se assim o índice de espi gas por planta.

Efetuadas essas determinações por ocasião da co Iheita, procedeu-se então às determinações de laboratório que consistiram de:

- Peso de espigas - Foram pesadas as espigas correspondentes à cada parcela, determinando-se assim, o peso de espigas por parcela em kilogramas $(\mathrm{kg})$.

- Peso de grãos - A seguir, as espigas foram de bulhadas eliminando-se os sabugos, após o 
que, nova pesagem foi efetuada àfim de 'se determinar o rendimento em grãos, para cada tra tamento, em kilogramas $(\mathrm{kg})$.

- Teor de umidade - O teor de umidade dos grãos, em porcentagem, para cada tratamento, foi determinada tomando-se uma amostra de 100 gramas de sementes previamente homogeneizadas em recipientes impermeáveis. A homogeneização das sementes em recipientes impermeáveis é ne cessária para que a determinação da umidade possa ser feita 24 horas após. As determinações foram feitas em um aparelho "Steinlite Eletronic Tester" modelo $G$.

\subsection{Correção dos dados}

Obtidos os valores para produção de grãos por parcela, o tear de umidade das sementes foi ajustado para $15,5 \%$, constante para todos os tratamentos, utilizando-se da seguinte fórmula:

$$
P_{15,5 \%}=\frac{P_{C}(1-U)}{(1-0,155)} \quad \text { onde: }
$$

$P_{15,5 \%}=$ Peso seco corrigido para $15,5 \%$ de umidade.

$P_{c} \quad=$ Peso de campo observado. 
U = Umidade observada.

$(1-0,155)$ = Expressa a matéria-seca quando a umidade é de $15,5 \%$.

As correções para um "stand" de 50 plantas por parcela, para cada parcela, foi realizada por meio da fórmula de ZUBER (1942), considerada como adequada para se obter uma boa estimativa da parcela em questão, desde que o número de plantas falhadas não supere a casa dos $20 \%$. A fórmula é a seguinte:

$$
P_{C C}=P_{C} \times \frac{H-0,3 F}{H-F} \quad \text { onde: }
$$

$P_{c c}=$ Peso de campo corrigido para $15,5 \%$ de umidade e "stand" de 50 plantas por parcela.

$P_{c}=$ Peso de campo em kg, corrigido para 15,5\% de umidade.

$H$ = "Stand" ideal ou número final de plantas por parcela.

F = Número de falhas por parcela.

Esta fórmula adiciona à produção, 0,7 do rendimento médio para cada planta falhada e considera que 0,3 de sua produção é recuperada pelo aumento da produtividade das plantas vizinhas. 


\subsection{Anālise estatisticà}

Com os dados de produção de grãos das parcelas, ajustados para umidade de $15,5 \%$ e "stand" ideal de 50 plantas por parcela, calculou-se a produção média para cada tratamento. A análise da variáncia dos dados de produção de grãos, após as correções, foram realizados segundo o esquema proposto por COCHRAN e coX (1957), para cada experimento. As análises foram realizadas como látice para os experimentos I e II, muito embora somente o delineamento em látice do experimento II mostrasse eficiência com relação ao de blocos ao acaso. o expe rimento II foi analisado normalmente como blocos ao acaso. No caso dos experimentos I e II, o teste F foi feito segundo indi cação de FEDERER (1955), usando o quadrado médio dos totais ajus tados dos tratamentos e a variáncia do erro efetivo, esta últi ma com o número de graus de liberdade do erro intra-bloco. Para expressar a eficiéncia dos delineamentos em látice,tomou-se a eficiência dos blocos ao acaso como sendo igual à 100\%. Com a finalidade de avaliar a precisão nas estimativas das médias dos tratamentos, foram calculados os coeficientes de variação dos très experimentos.

o quadrado médio de tratamentos foi decomposto àfim de separar os efeitos dos cruzamentos $S_{0} \times S_{0}$ chíbridos cripticos), das testemunhas e do grupo dos híbridos contra o grupo das testemunhas. Subtraindo-se do quadrado médio para 
híbridos crípticos o quadrado médio do residuo lde blocos casualizados ou do erro efetivo do látice, conforme houve ou não eficiêncial e, dividindo-se o valor assim obtido pelo número de repetições, de cada experimento, foi possível isolar a variância genética dos híbridos crípticos. Com esta estimativa ( $\sigma_{H . c .}^{2}$ ), calculou-se o coeficiente de variação genético para os híbridos crípticos nos três experimentos, ou seja:

$$
c . v \cdot \text { genético }=\frac{\sqrt{\sigma_{H}^{2}} \cdot c .}{\bar{x}} \times 100
$$

onde $\bar{x}$ é a média geral da produção de grãos dos híbridos críptí $\cos$.

Afim de se estudar comparativamente os resultados de produção entre todos os 176 cruzamentos $S_{0} \times S_{0}$, calculou-se a porcentagem de produção de grãos de cada híbrido $S_{0} \times S_{0}$ em relação à média das testemunhas Ag-152 R e Centralmex, nos três experimentos. Consequentemente, todos os dados tornaram-se comparativos entre sí.

Foi também realizada a análise da variância, co mo blocos ao acaso, para o caráter indice de espigas por planta, para os três experimentos. O quadrado médio de tratamentos foi decomposto, também nesse caso, àfim de se separar os efeitos dos cruzamentos $S_{0} \times S_{0}$, das testemunhas e do grupo dos híbridos contra o grupo das testemunhas. Foram também calculados, de acordo com o procedimento já descrito, o coeficien te de variação genético para os três experimentós, assim como 
os coeficientes de variação experimental.

\subsection{Seleção}

Com a finalidade de possibilitar o prosseguimento do método, necessitou-se efetuar uma seleção entre os 176 cruzamentos $S_{0} \times S_{0}$.

$$
\text { Praticou-se, então, uma seleção com intensidade }
$$
de $40 \%$, dos cruzamentos $S_{0} \times S_{0}$ de melhor performance apresentada nos testes de rendimento. Convém salientar que os cruzamentos superiores foram selecionados com base na porcentagem de produção, de cada cruzamentó, em relação à média das testemunhas Ag-152 R e Centralmex e não em termos de seus valores absoIutos. 


\section{RESULTADOS OBTIDOS}

\subsection{Produção de grãos}

Os resultados da análise da variáncia dos totais de produção por parcela de $10 \mathrm{~m}^{2}$, para o caráter peso de grãos, dos experimentos I, II e III, podem ser visualisados nas Tabelas 01,02 e 03 , respectivamente.

O ganho em eficiência do delineamento em látice, do experimento I, com relação ao de blocos ao acaso, foi relativamente pequeno e igual à 103,49\%. No experimento II, no en tanto, o ganho em eficiência pode ser considerado alto, sendo igual à 133,04\%. O reduzido ganho do delineamento em látice do experimento I, com relação ao de blocos ao acaso, pode ser explicado, segundo ARRUDA (1952), péla escolha acertada da posição das repetições no terreno, não obstante a utilização de parcelas de $10 \mathrm{~m}^{2}$. Dessa maneira, a componente da variação entre repetições foi suficiente para controlar a heterogeneida de do solo nesse experimento. A análise da variância, tanto 
para o experimento I como para o experimento II, foi, no entan to, realizada como látice, ajustando-se as médias dos tratamen tos.

o teste $F$ permite concluir que ocorreram diferenças significativas, ao nível de $1 \%$ de probabilidade, entre os os tratamentos, nos experimentos I e II. Não houve significân cia para as diferenças observadas entre os tratamentos do expe rimento III. A decomposição do efeito de tratamentos evidenciou as diferenças significativas entre os híbridos $S_{0} \times S_{0}$, ao nível de $1 \%$ de probabilidade, nos experimentos I e II sendo que, no experimento II essas diferenças não foram significativas. Foram constatadas diferenças significativas, ao nível de $1 \%$ de probabilidade, na comparação do grupo das testemunhas contra o grupo dos híbridos crípticos, nos experimentos I e II e significáncia para esse mesmo efeito, ao nível de 5\% de probabilidade no experimento III. Os resultados podem ser explicados pela grande variabilidade existente entre os cruzamentos $\mathrm{S}_{0} \times \mathrm{S}_{0}$. Deve ser salientado que a variabilidade dos compostos utilizados neste trabalho, é resultante da própria síntese dos mesmos.

Os coeficientes de variação dos experimentos I, II (látices) e III (blocos ao acaso) foram respectivamente iguais à $15,97 \%, 8,31 \%$ e $15,00 \%$, podendo ser considerados como médio, baixo e médio, respectivamente, de acordo com as condições experimentais dos ensaios em questão. 
A média geral de produção de grãos do experimen to I foi de $5.345 \mathrm{~kg} / \mathrm{ha}$, do experimento I de $5.755 \mathrm{~kg} / \mathrm{ha}$ e do experimento II de $5.560 \mathrm{~kg} / \mathrm{ha}$. Em se considerando as resultados obtidos nas experimentações do Instituto de Genética da ESALQ/USP, as médias podem ser consideradas como sendo boas.

A avaliação do grau de acamamento foi feita por meio da contagem das plantas acamadas e quebradas, por parcela, e o seu valor expresso em porcentagem do número de plantas por parcela na ocasião da colheita ("stand"). A Figura 06 apresenta a distribuição de frequências dos valores de acamamento em porcentagens do "stand" final (P), transformados para arc sen $\sqrt{P / 100}$, de todos os cruzamentos inclusos nos três expe rimentos, de maneira conjunta. A média geral de acamamento (plan tas acamadas mais plantas quebradas) do experimento I foi igual à 14,9\%, do experimento II igual à $10,1 \%$ e do experimento III foi igual à 4,8\%. O número médio de plantas por parcela do ex perimento I foi de 43,85, do experimento II de 44,30 e do experimento III de 42,60 , que equivalem à $87,7 \%, 88,6 \%$ e $85,2 \%$ do "stand" ideal de 50 plantas por parcela, para os experimentos I, I e III, respectivamente. Mesmo tendo ocorrido esta signi ficância, optou-se pela correção das produções para o número ideal de plantas por parcela.

As Tabelas 05, 06 e 07 mostram os resultados referentes ao peso de grãos, corrigidos para $15,5 \%$ de umidade e "stand" ideal de 50 plantas por parcela, dos tratamentos incluí 
dos nos três experimentos, respectivamente. As Tabelas apresentam também as porcentagens de produção de grãos, de cada crü zámento $S_{0} \times S_{0}$, em relação à média das testemunhas Ag-152 R e Centralmex, em cada experimento, o que torna os dados dos três experimentos comparáveis entre sí. Os dois compostos paternais não puderam ser incluídos como testemunhas nos ensaios, pela não disponibilidade de sementes dos mesmos, correspondentes ao ciclo de seleção entre e dentro de famílias de meios-irmãos em que se encontravam na época da realização dos cruzamentos. Como por um lapso os Compostos "Flint" e "Dentado", originais, também não foram incluídos nos ensaios,procurou-se efetuar uma extrapolação, utilizando-se, para tanto, de resultados do Ensaio Nacional do Milho, referentes aos períodos agrícolas de 1974/75, 1975/76 e 1976/77. O ensaio apresenta resultados referentes à produção de várias cultivares de milho, entre os quais dos Compostos "Flint" e "Dentado", da variedade Centralmex e do híbrido duplo Ag-152 R. Foi calculada a média da produção de grãos para essas cultivares, dos trés citados períodos e, por meio das mesmas, obtidos valores extrapolados pa ra os Compostos "Dentado" e "Flint", àfim de se estabelecer va lores relativos da heterose dos cruzamentos $S_{0} \times S_{0}$ com relação às duas populações paternais. -

0 rendimento médio dos 95 cruzamentos $S_{0} \times S_{0}$, incluidos no experimento I, foi de $5.37 \mathrm{lkg} / \mathrm{ha}$, com uma amplitude de $1.748 \mathrm{~kg} / \mathrm{ha}$ a $7.167 \mathrm{~kg} / \mathrm{ha}$. Nesse experimento a variedade Centralmex produziu $4.415 \mathrm{~kg} / \mathrm{ha}$, enquanto que a produtivi 
dade do Ag-152 R foi de $4.885 \mathrm{~kg} / \mathrm{ha}$. A média das duas testemunhas em questão foi, portanto igual à $4.650 \mathrm{~kg} / \mathrm{ha}$. Os valores extrapolados para os compostos paternais foram de 4.427 kg/ha para o Composto "Dentado" e de 4.431 kg/ha para o Compos to "Flint". Através destes valores observou-se que a média dos compostos paternais foi de $4.429 \mathrm{~kg} / \mathrm{ha}$. Comparando-se a média dos 95 cruzamentos $S_{0} \times S_{0}$ com a média dos pais (valores extrapolados), observou-se uma heterose (aproximada) de 1.302 kg/ha $(29,40 \%)$. A média dos cruzamentos foi $15,60 \%$ superior à média das testemunhas Ag-152 R e Centralmex. D coeficiente de variação genético para os 95 híbridos crípticos constantes des te experimento foi de $10,83 \%$. A figura 01 mostra a distribuição de frequências da produção de grãos, dos 95 híbridos crípti cos e dos 46 híbridos crípticos selecionados, correspondentes ao experimento I, expressa em \% das testemunhas Ag-I52 R e Ceㅡ tralmex.

Os 59 cruzamentos $S_{0} \times S_{0}$ incluídos no experimento II, tiveram um rendimento médio de $5.818 \mathrm{~kg} / \mathrm{ha}$, com uma amplitude de $2.781 \mathrm{~kg} / \mathrm{ha}$ a $9.719 \mathrm{~kg} / \mathrm{ha}$. As produções das testemunhas Ag-152 R e Centralmex foram, respectivamente, iguais à $6.210 \mathrm{~kg} / \mathrm{ha}$ e $4.713 \mathrm{~kg} / \mathrm{ha}$, o que resultou em uma produção mé dia de $5.462 \mathrm{~kg} / \mathrm{ha}$. Os valores extrapolados para os compostos paternais foram de 5.201 kg/ha para o Composto "Dentado" e de $5.205 \mathrm{~kg} / \mathrm{ha}$ para o Composto "Flint", sendo a média destes dois valores igual à $5.203 \mathrm{~kg} / \mathrm{ha}$. Da mesma forma anterior,com parando-se a média dos 59 cruzamentos $S_{0} \times S_{0}$ com a média dos 
pais (valores extrapolados), observou-se uma heterose (aproximada) de $615 \mathrm{~kg} / \mathrm{ha}(11,82 \%)$. A média dos cruzamentos foi, neste caso, 6,55\% superior às médias das testemunhas Ag-152 R e Centralmex. 0 coeficiente de variação genético para os 59 híbridos crípticos deste experimento foi de 13,91\%. A Figura 02 mostra a distribuição de frequéncia da produção de grãos, dos 59 híbridos crípticos e dos 14 híbridos crípticos selecionados, correspondentes ao experimento II, expressa em \% das testemunhas Ag-152 R e Centralmex.

Os 22 cruzamentos so $x$ so restantes, incluídos no experimento III, tiveram um rendimento médio de $5.682 \mathrm{~kg} / \mathrm{ha}$, variando de $4.568 \mathrm{~kg} / \mathrm{ha}$ a $8.358 \mathrm{~kg} / \mathrm{ha}$. As produções das testemunhas Ag-152 R e Centralmex foram, respectivamente, iguais à $5.235 \mathrm{~kg} / \mathrm{ha}$ e $4.56 \mathrm{l} \mathrm{kg} / \mathrm{ha}$, resultando em uma produção média de $4.898 \mathrm{~kg} / \mathrm{ha}$. Os valores extrapolados para os compostos paternais foram de $4.651 \mathrm{~kg} / \mathrm{ha}$ para o Composto "Dentado" e de $4.667 \mathrm{~kg} / \mathrm{ha}$ para o Composto "Flint", com uma média de $4.659 \mathrm{~kg} / \mathrm{ha}$. Assim, comparando-se a média dos 22 cruzamentos So x so com a média dos pais (valores extrapolados), observou-se uma heterose (aproximada) de $1.023 \mathrm{~kg} / \mathrm{ha}(21,95 \%)$. A média dos 22 híbridos crípticos, também neste caso superou a média das testemunhas Ag-152 R e Centralmex, desta feita em 16,00\%. 0 coeficiente de variação genético para os 22 híbridos crípticos inclusos no experimento II foi igual à $8,30 \%$. A Figura 03 mostra a distribuição de frequéncias de produção de grãos, dos 22 híbridos crípticos e dos 10 híbridos crípticos selecionados, 
correspondentes ao experimento III, expressa em $\%$ das testemunhas Ag-152 R e Centralmex.

No experimento I, $88(92,64 \%)$ dos cruzamentos So 0 So superaram a média das testemunhas Ag-152 R e Centralmex em produção de grãos. No experimento II, 40 (66,28\%) cruzamentos superaram a média das referidas testemunhas enquanto que, no experimento III, 20 (90,90\%) cruzamentos superaram a média das mesmas testemunhas.

Foram selecionados, dos 176 cruzamentos ensaiados, os 70 cruzamentos mais produtivos com relação à produção de grãos, o que corresponde à uma intensidade de seleção de $39,77 \%$ sendo, entre os cruzamentos selecionados, 46 correspondentes ao experimento I, 14 correspondentes ao experimento II e 10 correspondentes ao experimento III. Os cruzamentos selecionados juntamente com seus correspondentes de produção de grãos e com os valores de produção expressos em porcentagem da média das testemunhas Ag-152 R e Centralmex, em cada experimen to, podem ser encontrados na Tabela 8. A Figura 04 mostra a distribuição de frequēncia da produção de grãos, dos 176 híbridos crípticos e dos 70 híbridos crípticos selecionados, correspondentes aos trés experimentos, expressa em \% das . testemunhas Ag-152 R e Centralmex. 


\subsection{Indice de espigas por planta}

A Tabela 4 apresenta os resultados da análise da variáncia para o caráter índice de espigas por planta, para os trés experimentos. A análise foi realizada como blocos ao acaso pelo fato do látice normalmente não apresentar eficiéncia para este caráter.

O teste f evidenciou a ocorrência de diferenças significativas, ao nível de $5 \%$ de probabilidade,entre os trata mentos do experimento I, diferenças significativas, ao nível de $1 \%$ de probabilidade, entre os tratamentos do experimento II e diferenças não significativas entre os tratamentos do experimento III. A decomposição do efeito de tratamentos demonstrou a ocorréncia de diferenças significativas, aos níveis de $5 \%$ e $1 \%$ de probabilidade, entre os cruzamentos $s_{0} \times S_{0}$ nos experimentos I e II, respectivamente, enquanto que no experimento III não foi constatada significāncia nas diferenças entre os cruzamentos. Foram constatadas diferenças significativas, ao nível de $1 \%$ de probabilidade, na comparação do grupo dos crü zamentos (híbridos crípticos) contra o grupo das testemunhas, nos trés experimentos.

Os coeficientes de variação para os experimentos I, II e III foram de $12,71 \%, 10,55 \%$ e $17,78 \%$, respectivamente, valores estes que podem ser considerados como médios pạ ra as condições experimentais dos ensaios em questão. Os índi- 
ces médios de espigas por planta para os experimentos I, I e II foram respectivamente de 1,04, 1,03 e 0,96.

o indice médio de espigas por planta dos cruzamentos $S_{0} \times S_{0}$, incluídos no experimento $I$, foi de 1,05, com uma amplitude de 0,85 a 1,28 espigas por planta. Os índices das testemunhas Centralmex e Ag-152 R foram de 0,88 e 0,98 espigas por planta, respectivamente, o que resultou em 0,93 espigas por planta em termos de média das duas testemunhas. o coeficiente de variação genético pará o caráter em questão, nesse experimento, foi de $5,22 \%$.

No experimento II, o indice médio de espigas por planta dos 59 cruzamentos $S_{0} \times S_{0}$ nele incluídos, foi de 1,11, com uma amplitude de 0,86 a 1,62 espigas por planta. As testemunhas Ag-152 R e Centralmex apresentaram índices iguais à 0,95 e 0,9l espigas por planta, respectivamente, com uma média de 0,93 espigas por planta. O coeficiente de variação genético para o caráter índice de espigas por planta, no experimento II, foi de $9,50 \%$.

o experimento III, por seu turno, apresentou um Índice médio de espigas por planta igual à 1,18 , de seus 22 cru zamentos, com uma amplitude de 0,82 a 1,55 espigas por planta. As testemunhas Ag-152 R e Centralmex apresentaram índices de 0,86 e 0,92 espigas por planta, respectivamente, com uma média de 0,89 espigas por planta. O coeficiente de variação genético para os 22 cruzamentos do experimento III foi igual à $7,29 \%$. 
Como consequéncia da seleção dos $39,77 \%$ melhores cruzamentos $S_{0} \times S_{0}$, dos trés experimentos, nota-se que no material selecionado, houve um aumento no indice de espigas por planta para 1,08 no experimento I, para 1,22 no experimento I sendo que esse valor, não se alterou para o experimento III, permanecendo igual à 1,l8. Estes valores corresponderam à diferenciais de seleção iguais à $0,04,0,12$ e 0,00 espigas por planta, nos experimentos I, II e III, respectivamente. As Tabelas 5, 6 e 7 mostram os valores de índice de espigas por planta para todos os tratamentos inclusos nos experimentos I, II e III, respectivamente, e a Figura 5 apresenta a distribuição de frequēncias dos índices de espigas por planta, transfor mados em $\sqrt{x}$, dos 176 cruzamentos $S_{0} \times S_{0}$ e dos 70 cruzamentos So x So selecionados, dos trés experimentos, de maneira conjun ta. 


\section{DISCUSSAO}

A técnica de obtenção das autofecundações e crü zamentos controlados, como originalmente proposta e empregada por HALlauer (1967a, 1967b, 1973), consiste da realização, em uma primeira etapa, dos cruzamentos entre as plantas dos dois compostos, utilizando-se para tanto de suas espigas inferiores e, numa etapa posterior, da realização das autofecundações, utilizando-se desta feita das espigas superiores das plantas anteriormente cruzadas. A técnica empregada neste trabalho, diferiu um pouco da original, no sentido de que foram realiza das primeiramente as autofecundações, utilizando-se das espigas inferiores das plantas selecionadas nos dois compostos e, numa segunda etapa, realizados os cruzamentos entre as plantas previamente autofecundadas, utilizando-se de suas espigas superiores. Este procedimento visa a obtenção de um maior número de sementes necessárias à avaliação dos cruzamentos em en saios de rendimento, haja visto que as espigas superiores são, normalmente, mais produtivas que as inferiores. Este procedi 
mento foi também utilizado por LONNQUIST e WILLIAMS (1967) e LOPES (1974). MAGNAVACA (1973) sugeriu uma modificação à essa técnica que consiste em se autofecundar as plantas à serem uti lizadas como fornecedoras de pólen, no mesmo dia em que são realizados os cruzamentos. Dessa forma evita-se a realização de uma operação a mais no campo, pois os pendões não necessitam ser protegidos por duas vezes por sacos de papel impermeável. Este procedimento também diminui o risco de ter-se pouco pólen para os cruzamentos, tendo em vista que estes seriam retardados por dois dias se necessário fosse "ensacar" os pendões por duas vezes. No entanto, este procedimento aumenta consideravelmente o risco de ocorréncia de contaminação por pólen estranho, motivo pelo qual não foi utilizado no presente trabalho.

Observa-se que a técnica utilizada é bastante trabalhosa e requer bastante habilidade pessoal na sua execução, além de depender da prolificidade das populações utilizadas. Este caráter também se constitui em um fator de primordial importáncia pois, quanto maior for a prolificidade na população, maior o aproveitamento dos cruzamentos $S_{0} \times S_{0}$. Foram realizados, no presente trabalho, I.000 cruzamentos e 2.000 a tofecundações correspondentes, onde nem todos os cruzamentos produziram sementes suficientes para os ensaios ou não possuiam sementes correspondentes $S_{1}$, necessárias ao prosseguimento do método nas etapas seguintes. Assim sendo, foram obtidos 176 cruzamentos So x So com as respectivas sementes de autofecun 
dação $S_{1}$ correspondentes à cada par de plantas cruzadas. Deve-se salientar que não foram realizados os cruzamentos recíprocos entre as plantas dos dois compostos, àfim de se obter um maior número de cruzamentos em detrimento do nümero de sementes para cada cruzamento. Segundo MAGNAVACA (1973), uma pequena limitação do método utilizado, seria o pequeno número de sementes obtido, não permitindo testes muito intensos pela limitação do número de locais e/ou anos, repetições e, até mesmo do tamanho das parcelas. Entretanto, no caso do presente trabalho, pode-se verificar que o nümero de repetições utiliza das nos trés experimentos, ou seja, experimentos I, II e III com 4,3 e 2 repetições, respectivamente, embora reduzido, foi suficiente para permitir a seleção dos melhores cruzamentos, em níveis médios de precisão de estimativa das médias,como pode ser constatado pelos coeficientes de variação dos ensaios em questão. O aumento do nümero de locais elou anos e de repe tições, iria, certamente, restringir o número de tratamentos possíveis de serem testados.

Ainda com respeito à prolificidade dos compostos, pode-se constatar que o Composto "flint" apresenta maior prolificidade que o Composto "Dentado". Assim sendo, sugere-se que, quando da utilização desses dois compostos para a extração de linhagens pelo método dos híbridos crípticos, o Composto "Dentado" seja sempre utilizado como fornecedor de pólen pa ra os cruzamentos, àfim de ser maximizada a eficiência da obtenção de conjuntos completos de trés espigas (trincas), corres- 
pondentes ao cruzamento e às duas autofecundações, correspondentes às plantas que participaram deste cruzamento. Este procedimento, muito embora não contribua para a manutenção da prọ lificidade das linhagens extraidas do Composto "Dentado", contribui para a manutenção da mesma nas linhagens oriundas do Com posto "flint", o que é importante para o prosseguimento do método.

Com base nos valores apresentados nas Tabelas 05, 06 e 07, observa-se que, entre os 176 cruzamentos So $x$ So testados, 119 apresentaram rendimentos superiores ao híbrido duplo Ag-152 R e, 161 cruzamentos superaram a média da varieda de Centralmex. Deve-se ressaltar que essas duas cultivares, utilizadas como testemunhas no presente estudo, são bastante cultivadas no Estado de São Paulo e, em particular no Município de Piracicaba, face a alta produtividade das mesmas. Esta superioridade inicial dos cruzamentos $S_{0} \times S_{0}$ interpopulacionais, quando comparados ao híbrido e à variedade controles, é devida à cruzamentos que envolvem plantas superiores nas duas populações paternais, como consequéncia do prévio melhoramento dessas populações. Desta forma, os resultados estão de acordo com os obtidos por LONNQUIST e WILLIAMS (1967) e com a sugestão de LONNQUIST (1951, 1961$)$ e PATERNIANI (1966, 1969) para o melhoramento de populações, àfim de torná-las melhores fontes de linhagens endogàmicas superiores. 
A comparação entre as médias de produção dos 176 híbridos crípticos, mostra haver diferenças negativas e positi vas, com uma variação de $39,47 \%$ à $186,80 \%$ em relação à média dos compostos paternais. Estes resultados, muito embora oriun dos de valores extrapolados para a médias dos compostos pater nais e, portanto, não dignos de muita confiança, são bastante expressívos e estão de acordo com aqueles observados por HALLAUER (1967a, 1967b), LONNQUIST e WILLIAMS (1967), SILVA (1970), MAGNAVACA (1973), LOPES (1974) e ZINSLY (1977), que ve rificaram grande variação entre os cruzamentos $S_{0} \times S_{0}$. Considerando-se a média dos 176 cruzamentos $S_{0} \times S_{0}$, constatou-se que houve uma heterose (aproximada) de $21,06 \%$ com relação à mé dia dos compostos paternais (valores extrapolados). Este valor, além das implicações já mencionadas referentes à extrapolação dos valores de produção dos compostos paternais,estão co mumente sujeitos à flutuações devidas às interações por anos e/ou locais e à própria variabilidade dos citados compostos. Altos valores para heterose de produção de grãos têm sido comumente encontrados em cruzamentos $\left(S_{0} \times S_{0}\right)$ de irmãos germanos, conforme os estudos de LONNQUIST e WILLIAMS (1967), HALLAUER (1967a, 1967b, 1973), SILVA (1970), MAGNAVACA (1973); LOPES (1974) e ZINSLY (1977) e, de acordo-com ZINSLY (1977), mesmo em cruzamentos intervarietais, têm sido encontrados altos valo res para a heterose em relação à média dos pais, conforme estu dos realizados por RICHEY (1922) e de PATERNIANI e LONNQUIST (1963). Entretanto, MIRANDA F' e VENCOVSKY (1974) realizando uma análise 
genética através de cruzamentos dialélicos entre diferentes va riedades de milho, encontrou um valor negativo (- 0,176) para a heterose de produção do cruzamento entre os compostos "Flint" e "Dentado". Comparando-se esses resultados com o resultado obtido pelo presente trabalho, conclui-se que o valor igual à $21,06 \%$ para a heterose de produção, muito embora aproximado, é bastante expressivo e significativo. A utilização de progênies de irmãos germanos interpopulacionais foi, portanto,efetiva no aumento da heterose entre os dois compostos. Deve-se salientar que os Compostos "Flint" e "Dentado" não foram formados de maneira que o cruzamento entre os mesmos fosse heterótico. Por estes resultados pode-se sugerir o emprego do esquema de seleção recorrente recíproca em famílias de irmãos germanos, àfim de se obter duas populações mais heteróticas, mais produtivas e com alta homogeneidade, à partir da recombinação entre plantas $S_{1}$ selecionadas em cada um dos compostos.

Praticou-se uma seleção com uma intensidade de $39,77 \%$, dos cruzamentos de melhor performance apresentada nos testes de rendimento. Esta intensidade suave de seleção foi proposta e praticada, pelo fato da impossibilidade de serem testados intensamente os cruzamentos obtidos. Este procedimen to está de acordo com a sugestão de HALLAUER (1967a, 1967b) pa ra que seja efetuada uma seleção com uma intensidade de $30 \%$ a $50 \%$, dos cruzamentos que mais produziram nos testes de rendimento. No caso do emprego, à partir dos $\mathrm{S}_{1}$ selecionados, do 
esquema de seleção recorrente recíproca em famílias de irmãos germanos, sugere-se que sejam selecionados somente $10 \%$ dos meIhores cruzamentos. Quando aplicou-se a seleção com intensida de de $39,77 \%$, observou-se um diferencial de seleção de + $12,44 \%$, em termos de heterose porcentual. Esse resultado mostra a gran de variabilidade existente nos dois compostos paternais e que, - aproveitamento dessa variabilidade pode ser melhor efetuado por meio de seleção entre famílias de irmãos germanos.

Deparando-nos com os valores obtidos para os coe ficientes de variação genética, dos três experimentos, e que resultaram em um coeficiente de variação genético médio igual à $11,01 \%$, verificou-se que os experimentos mostraram suficien te precisão para detectar diferenças genéticas entre os híbridos crípticos avaliados.

PATERNIANI (1976) estudando a produção de grãos em progênies de meios-irmãos intrapopulacionais, em um esquema de seleção entre e dentro de famílias de meios-irmãos, nos Compostos "Flint" e "Dentado", obteve valores para os coeficientes de variação genética iguais à $5,8 \%$ para o composto "flint" e 7,1\% para o Composto "Dentado". A comparação desses valores com aqueles obtidos no presente trabalho, pela utilização de progênies de irmãos germanos, nas mesmas populações, demonstra como a seleção baseada em famílias de irmãos germanos, libera mais rapidamente a variabilidade genética. Quanto ao tipo de variância genética, o método dos híbridos crípticos faz uso 
tanto da variância genética aditiva como da dominante. Se a epistasia for importante, este método também deve ser vantajoso.

Podem ser consideradas como razoáveis as porcentagens de plantas acamadas e quebradas, tanto para os híbridos crípticos como para as testemunhas, nos três experimentos, como pode ser observado na Figura 06 . Estes caracteres são muito difíceis de serem avaliados com precisão devido à fatores incontroláveis do ambiente. A elevada altura das plan tas dos compostos estudados, pode ser um dos fatores mais sérios, quando se pretende obter dados mais precisos com relação à esses caracteres. A própria prolificidade das plantas pode ter influência no acamamento. Na grande maioria das populações adaptadas às nossas condições, quase sempre as plantas prolíficas são mais susceptíveis a acamamento, devido ao maior peso sobre as plantas, principalmente se as espigas estiverem localizadas na metade superior do colmo (relação: altura da es pigalaltura da planta $>0,5)$. A utilização de plantas de porte baixo, portanto, provavelmente minimizaria esse problema. A introdução do gene br 2 (braquítico-2), também poderia se constituir em uma alternativa, desde que fosse introduzido nas linhagens $S_{1}$, dos Compostos "Flint" e "Dentado". A introdução de genes maiores condicionando caracteres especificos no "background" genético de linhagens já próximas da homozigose, por meio de retrocruzamentos, não se constitui em uma prática 
aconselhável. Por esta razão, este procedimento, sendo realizado em linhagens $S_{1}$, portadoras de ainda alta heterozigosidade, não se constituiria em um problema no tocante à sua aplica Ção •

o número médio de plantas por parcela na ocasião da colheita ("stand") foi de 44 plantas, equivalente à 87,16\% do "stand" ideal de 50 plantas. Mesmo assim, optou-se pela correção para um número ideal de plantas por parcela. Assim procedendo, procurou-se obter maior precisão na comparação dos híbridos crípticos, com um "stand" próximo do ideal. Na ma neira do possível procurou-se selecionar os cruzamentos com um "stand" superior à $80,00 \%$, isto é, aqueles cujo número de plan tas falhadas não ultrapassaram a casa dos $20 \%$.

Verifica-se pelos índices de espigas por planta obtidos, que, tanto os híbridos crípticos como as testemunhas, na densidade de plantio de 50.000 plantas por hectare utilizada neste trabalho, apresentaram baixos números de espigas por planta, ocorrendo inclusive, muitas plantas sem espigas. Verifica-se também que, a seleção baseada diretamente na produção de grãos, afetou favoravelmente, embora em pequenas proporções, o número médio de espigas por planta.

Durante o programa de obtenção de linhagens pelo método dos híbridos crípticos, é de essencial importància que 
- caráter prolificidade seja mantido, àfim de que o método pro posto possa ser empregado em todas as gerações de autofecundações e cruzamentos. Paralelamente deve ser salientado que o número de espigas é também um dos componentes de produção de grãos em milho. Entretanto, a prolificidade é prejudicada com - avanço das gerações de endogamia, o que é confirmado por ZINSLY (1977). Os compostos utilizados por HALLAUER (1967a, 1967b, 1973) e por LONNQUIST e WILLIAMS (1967), em seus trabalhos, onde aplicaram o método em questão, eram pré-seleciona dos e obtidos por recombinação de linhagens de boas caracterís ticas agronômicas. Dessa forma, é de se esperar que esses com postos sofram menos os efeitos da endogamia pois, duranteo pro cesso de obtenção dessas linhagens, os genes deletérios são eli minados, ao passo que, os compostos obtidos por recombinação de variedades ou populações, como no presente caso, quando da obtenção das linhagens $S_{1}, S_{2}$, e assim por diante, aparecerão os caracteres indesejáveis, controlados por genes deletérios. Este se constitui em um dos maiores problemas quando da escolha das populações paternais à serem utilizadas como fonte de extração de linhagens, pelo método dos híbridos crípticos.

Infelizmente, pelos motivos já expostos, não foi possível calcular-se a heterose para este caráter. No entanto, comparando-se a média dos híbridos crípticos com a média das testemunhas Ag-152 R e Centralmex, para o caráter índice de espigas por planta, nota-se uma superioridade dos híbridos equivalente à 0,2 espigas por planta, com relação àquelas teste 
munhas. Nos cruzamentos selecionados observou-se, concomitantemente ao aumento do rendimento de grãos, um aumento no índice de espigas por planta. Os resultados, assim obtidos, mostraram a possível correlação positiva entre produção e prolifi cidade. Dessa forma, os resultados estão de acordo com aqueles obtidos por FREEMAN (1955), JOSEPHSON (1957, 1961$)$, COLLINS, RUSSEL e EBERHART (1965) e ZINSLY (1977). Os resultados obtidos mostraram ainda a importáncia da segunda espiga para o aumento da produção, conforme já anteriormente verificado por BAUMAN (1960), LONNQUIST (1967) e HALLAUER (1973).

A principal desvantagem do método tradicional de obtenção de milhos híbridos, reside na obtenção aleatória das linhagens. 0 valor de uma linhagem consiste, principalmente, na sua capacidade de produzir bons cruzamentos, o que pelo método tradicional, é conhecido somente ao final do processo de endogamia. Assim sendo, muitas das linhagens comboas características agronómicas e boa produtividade, obtidas ao final de um longo processo de autofecundações e de seleção, podem ser eliminadas por não possuirem capacidade de produzir bons híbridos. Além desses incovenientes, existe a dificuldade de se conseguir bons testadores para as linhagens. Poderia se considerar como um bom testador, aquele que fosse contrastante com as linhagens em relação ao caráter em estudo. Assim,se - caráter à ser testado é a produtividade, o testador deve ser de baixa produtividade. Mas, como os híbridos são julgados 
também para caracteres outros, além da produtividade, surge en tão a dificuldade de se conseguir testadores que preencham bem todos os quesitos necessários.

o método dos híbridos crípticos foi planejado para maximizar a seleção entre pares de genótipos, com base na sua performance de rendimento, em combinações híbridas. Dessa forma, difere da maioria dos métodos de melhoramento de milho, pois são selecionados pares de genótipos, ao invés de genótipos individuais, à cada geração de endogamia. Assim sendo, e te método elimina as desvantagens anteriormente mencionadas pa ra o método tradicional pois, somente entre bons cruzamentos (híbridos) é que são mantidas as linhagens. A capacidade espe cífica de combinação é, por este método, avaliada à cada geração de autofecundação das linhagens, pelo isolamento de híbridos (ou famílias de irmãos germanos) o que, além de eliminar a necessidade de testadores, reduz consideravelmente o tempo requerido na obtenção de linhagens de milho.

Desde que ós Compostos "Flint" e "Dentado" não foram formados de maneira tal que, o cruzamento dos mesmos seja heterótico e, diante da heterose obtida entre os dois compostos, pelo isolamento de famílias de irmãos germanos, visualisa-se a possibilidade do emprego de um esquema de seleção recorrente recíproca em famílias de irmãos germanos, nessas duas populações, àfim de se obter duas populações mais heteróticas 
.56.

e mais produtivas. Assim essas duas populações poderiam ser utilizadas efetivamente na redução do tempo requerido para o desenvolvimento de híbridos superiores, de acordo com LONNQUIST e WILLIAMS (1967). 


\section{CONCLUSÕES}

Dos resultados obtidos podem ser extraídas seguintes conclusões:

- A heterose obtida, comparando-se a média dos cruzamentos: $S_{0} \times S_{0}$ com a média dos Compostos "Flint" e "Dentado", paternais, sugere que e tes compostos constituem-se em boas fontes de obtenção de linhagens, pelo método proposto.

- A obtenção de cruzamentos $S_{0} \times S_{0}$ mais produtivos que o híbrido duplo $\mathrm{Ag}-152 \mathrm{R}$ e a variedade Centralmex, bastante produtivos e utilizados como testemunhas, comprova a eficiência do método para a identificação de cruzamentos específicos superiores, obtidos à partir de duas populações previamente selecionadas. 
- O elevado rendimento de alguns híbridos críptí cos, na primeira etapa do método, demonstram uma redução no tempo requerido para a obtenção de híbridos de milho.

- O aumento verificado no índice de espigas por planta, correspondente ao aumento da produção, indica a eficiência do método em aumentar a prolificidade.

- A aplicação de fracas intensidades de seleção, na primeira etapa do método, possibilita a ma nutenção de uma maior variabilidáde genética para permitir a continuidade do método.

- A utilização de somente uma espiga,dentro de ca da par de plantas, para o cruzamento entre as mesmas, é suficiente para a avaliação prelimi nar dos híbridos crípticos assim obtidos.

- O uso de progénies de irmãos germanos interpopulacionais quando comparado ao uso de progênies de meios-irmãos intrapopulacionais, libe ra mais rapidamente a variabilidade genética, nas duas populações em questão. 
- A utilização de um esquema de seleção recorren te recíproca em famílias de irmãos germanos, possibilitaria o aumento da heterose entre os Compostos "Flint" e "Dentado". 


\section{SUMMARY}

This work was conducted to evaluate the yield and number of ears per plant of $176 S_{0} \times S_{0}$ full-sib families (criptic doubles crosses), obtained from the cross between "Flint" and "Dent" Composites, corresponding to the first step of the method proposed by HALLAUER (1967a) and LONNQUIST and WILLIAMS (1967). "Flint" and "Dent" Composites were synthetized in the Instituto de Genética, ESALQ/USP, and are characterized by high yield associated with prolificacy and great variability. Crossing and selfing were initiated after several generations of selection among and within half-sib families.

The 176 crosses were evaluated in yield trials, using double cross $\mathrm{Ag}-152 \mathrm{R}$, the variety Centralmex and three other populations as checks. In the comparisons estimated yields of "Flint" and "Dent" Composites from other trials were used because they were not included as checks in the full-sib progeny trials. 
The following conclusions can be formulated. from the results herein analysed:

- Hybrid vigour observed in crosses suggest that the parental populations are good source of inbred lines to be used in crosses.

- The first phase of hybrid development from full-sib progenies showed to be effective as indicated by the outstanding $S_{0} \times S_{0}$ crosses, relative to yield of commercial checks. The identification of superior crosses in the early generations also represents an advantage that must be accounted for in the evaluation of the method.

- The method under evaluation also showed to be effective to increase the number of ears per plant thus indirectly increasing yield. Such a response occurred despite of the low selection intensity used in the first step. A low selection pressure also assures enough amount of genetic variability to be in the further cycles of selection.

- Genetic variability showed to be greater among interpopulational full-sib families than that expressed among intrapopulational half-sib families, for the same populations.

- A reciprocal recurrent selection based an full-sib families would make possible the increase of the heterosis in the cross between "Flint" and "Dent" Composites. - One crossed ear for each pair of $S_{0}$ plants was sufficient for the evaluation of full-sib progenies in the yield trials. 


\section{LITERATURA CITADA}

ANDERSON, D.C., 1938. The Relation Between Single and Double

Cross Yields in Corn. Journal of the American Society of Agronomy. Madison, 30:209-211.

ARRUDA, H.V., 1952. Precisão dos Delineamentos Tipo Lattice em Milho. Bragantia. Campinas, 12 (10/12):309-313.

BAUMAN, L.F., 1960. Relative Yield of First (apical) and Second Ears of Semi-Prolific Southern Corn Hybrids. Agronomy Journal. Madison, 52(4):220-222.

BEAL, W.J., 1877. Report of the Professor of Botany and Horticulture. Rept. Mich. Bd. Agr., p.4l-59. In: SPRAGUE, G.F., 1955. Corn and corn improvement. New York, Acad. Press Inc. Publ., cap. 5, p.226. 
BURNHAM, C.R., 1946. An "Oenothera" or Multiple Translocations Method of Establishing Homozygous Lines. Journal of the American Society of Agronomy. Madison, 38:702-707.

CASTRO, G.M.; GARDNER, C.0. e LONNQUIST, J.H., 1968. CUmUla= tive Genes Effects and the Nature of Heterosis in Maize Crops Involving Genetically Oiverses Races. Crop Science. Madison, 8(1):97-101.

CHASE, S.S., 1949. Monoploid Frequencies in a Commercial Double Cross Maize and in its Component Single Cross Hybrids and Inbred Lines. Genetics. Princeton, 34(3): $328-332$.

CHASE, S.S., 1952. Production of Homozigous Diploids of Maize from Monoploids. Agronomy Journal. Washington, 44(5): $263-267$.

COCHRAN, W.G. e COX, G.M., 1957. Experimental Designs. $2^{\text {nd }}$ Ed. John Wiley \& Sons. New York. 6IIp.

COLLINS, W.K.; RUSSEL, W.A. e EBERHART, S.A., 1965. Performance of two-ear type of Corn Belt Maize. Crop Science, Madison, $5(2): 113-116$.

DOXTATOR, C.V. e JOHNSON, I.J., 1936. Prediction o.f Double Cross Yields in Corn. Joumal of the American Society of Agronomy. Madison, 28:460-462. 
.64.

EAST, E.M., 1908. Inbreeding in Corn. Rept. Conn. Agr. Expt. Sta. for 1907. P.419-428. In: SPRAGUE, G.F., 1955. Corn and Corn Improvement. New York, Acad. Press Inc. Publ. cap. 5, p.234.

EAST, E.M., 1909. The Distinction Between Development Heredity in Inbreeding. American Naturalist. Lancaster, 43:173-181. In: SPRAGUE, G.F., 1955. Corn and Corn Improvement. New York, Acad. Press Inc. Publ. cap.5, p.234.

EBERHART, S.A.; HARRISON, M.N. e OGADA, R., 1967. A Comprehensive Breeding System. Der Züchter, Berlin, 37(4):169-174.

FEDERER, W.T., 1955. Experimental Designs. Macmillan Co. New York. 544 p.

FREEMAN, W.H., 1955. Evaluating Hybrids in the South. Proceedings of the Hybrid Corn Industry Research Conference. Chicago, 10:24-31.

GOMES, F.P., 1970. Curso de Estatistica Experimental. 4a. Ed. São Paulo, Ed. Nobel. 430 . .

HALLAUER, A.R., $1967(a)$. Development of Single-cross Hybrids from Two-Eared Populations. Crop Science. Madison, 7(3): $192-195$. 
HALlaUeR, A.R., 1967 (b). Performance of Single-Cross Hybrids Developed from Two-Ear Varieties. Proceedings of the Hybrid Corn Industry Research Conference. Chicago, 22: $74-81$.

HAllauer, A.R. e EBerhart, S.A. , 1970. Reciprocal Full-sib Selection. Crop Science. Madison, 10(3):315-316.

HALLAUER, A.R., 1973. Hybrid Development Populations Improvement in Maize by Reciprocal Full-sib Selection. Egyptian Journal of Genetics and Cytology. Cairo, 2(1): 84-101.

HALLAUER, A.R., 1975. Inbred and Hybrid Development from Improved Maize Populations. Eucarpia, 8eme Congrés International de la Section Mäis-Sorgho, Paris-Versailles, septembre, 1975 .

HAYES, H.K. E JOHNSON, I.S., 1939. The Breeding of Improved Selfed Lines of Corn. Journal of the American Society of Agronomy. Washington, 31:710-724.

JENKINS, M.T., 1934. Method of Estimating the Performance of Double Cross in Corn. Journal of the American Society of Agronomy. Madison, 26:199-204. 
JENKINS, M.T., 1940. The Segregation of Genes Affecting Yield of Grain in Maize. Journal of the American Sosiety of Agronomy. Washington, 32:55-63.

JOHNSON, I.S. e HAYES, H.K., 1940. The Value in Hybrid Combinations of. Inbred Lines of Corn Selected from Single Crosses by the Pedigree of Breeding. Journal of the American Society of Agronomy. Washington, 32:479-485.

JONES, O.F., 1918. The Effect of Inbreeding and Crossbreeding upon Development. Conn. Agr. Expt. Sta. Bull., 207:5-100. In: SPRAGUE, G.F., 1955. Corn and Corn Improvement. New York, Acad. Press Inc. Publ., cap.5, P.234.

JONES, D.F. e SINGLETON, W.R., 1934. Crossed Sweet Corn. Conn. Agr. Expt. Sta. Bull., 361:489-536. Apud. PATERNIANI, E., 1966. Genética e Melhoramento do Milho. In: Cultura e Adubação do Milho. São Paulo, Ed. Inst. Bras. Potassa. cap.4, p.109-151.

JOSEPHSON, L.M., 1957. Breeding for Early Prolific Hybrids. Proceedings of the Hybrid Corn Industry Research Conference. Chicago, 10:24-31.

JOSEPHSON, L.M., 1961. Combining Prolificacy and Earliness. Proceedings of the Hybrid Com Industry Research Conference. Chicago, 16:45-52. 
JUGENHEIMER, R.W., 1958. Hybrid Maize Breeding and Seed Production. Rome, FAO. 432pp. (FAO Agri. Development Paper J.

LONNQUIST, J.H., 1949. The Development and Performance of Synthetic Varieties of Corn. Agronomy Journal. Washington, $41(4): 153-156$.

LONNQUIST, J.H., 1950. The Effect of Selection for Combining ability Within Segregating Lines of Corn. Agronomy Journal. Washington, 42(10):503-508.

LONNQUIST, J.H., 1951. Recurrent Selection as a Means of Modifying Combining Ability in Corn. Agronomy Journal. Washington, $43(7): 311-315$.

LONNQUIST, J.H., 1961. Progress from Recurrent Selection Procedures for the Improvement of Corn Populations. Nebraska Agriculture Experiment Station Research Bulletin. 197.

LONNQUIST, J.H., 1967. Mass Selection for Prolificacy in Maize. Der Züchter. Berlin, 37(4):185-188.

LONNQUIST, J.H. e WILLIAMS, N.E., 1967. Development of Maize Hybrids through Selection Among Full-sib Families. Crop Science. Madison, 7(4):368-369. 
.68.

LOPES, A.M., 1974. Avaliação de Híbridos Crípticos entre Dois Compostos de Milho (Zea mays L.) na Primeira Geração de Intercruzamento. Piracicaba, ESALQ/USP. 55 . (Dissertação de Mestrado).

MAgnavacA, R., 1973. Aplicação de Método dos Híbridos Crípticos para a Obtenção de Linhagens de Milho (Zea mays L.). Piracicaba, ESALQ/USP. 50p. (Dissertação de Mestrado).

MIRANDA FILHO, J.B. e VENCOVSKY, R., 1974. Análise Genética através de Cruzamentos Dialélicos entre Diversas Variedades de Milno. Relatório Cientifico do Instituto de Genéti ca. ESALQ/USP. Piraciçaba, (8):121-127.

MORO, J.R.; ZINSLY, J.R. e PATERNIANI, E., 1974. Seleção Recorrente Recíproca em Famílias de Irmãos Germanos de Milho lZea mays L.I. ReZatório Cientifico do Instituto de Genética. ESALQ/USP. Piracicaba, ( 8 ):139-147.

MORROW, G.E. e GARDNER, F.D., 1893. Field Experiment with Corn. III Agr. Expt. Sta. Bull., 2. In: JUGENHEIMER, R.W., 1958. Hybrid Maize Breeding and Seed Production. Rome, FAO. 432p. (FAO Agric. Development Paper n'62).

PATERNIANI, E. e LONNQUIST, J.H., 1963. Heterosis in Interracial Crosses of Corn (Zea mays L.). Crop Science, 3:504-507. 
PATERniAni, E., 1966. Genética e Melhoramento de Milho. In: Cultura e Adubaç̃o do Milho. São Paulo, Ed. Inst. Bras., Potassa, cap.4, p.109-151.

PATERnIANI, E., 1968. Formação de Compostos de Milho. Relatörio Cientifico do Instituto de Genética. ESALQ/USP, Piracicaba, (2):102-108.

PATERNIANI, E., 1969. Melhoramento Genético de Populações de Milho. In: KERR, W.E., 1969. Melhoramento e Genética. São Paulo, Ed. USP, cap.2, P.39-59.

PATERNIANI, E., 1976. Seleção Entre e Dentro de Famílias de Meios Irmãos nas Populações Dentado Composto e Flint Composto. Relatório Cientifico do Instituto de Genética. ESALQ/USP, Piracicaba, (10):161-166.

PATERNIANI, E.; ZINSLY, J.R. e MIRANDA FILHO, J.B. DE, 1977. Populações Melhoradas de Milho Obtidas pelo Instituto de Genética. Relatörio Cientifico do Instituto de Genética. ESALQ/USP. (No prelo).

RICHEY, F.D., 1927. The Convergent Improvement of Selfed Lines of Corn. American Naturalist. Lancaster, 61:430-449. Apud. PATERniani, E., 1966. Genética e Melhoramento do Mi1ho. In: Cultura e Adubação de Milho. São Paulo, Ed. Inst. Bras. Potassa. cap.4, p.109-151. 
RICHEY, F.D., 1950. Corn Breeding. Advances in Genetics. New York, 3:159-192.

SHULL, G.H., 1908. The Composition of a Field of Maize. Am. Breed. Assoc. Rept. 4:296-301. In: SPRAGUE, G.F., 1955. Corn and Corn Improvement. New York, Acad. Press Inc. Publ. cap.5, p.234.

SHULL, G.H., 1909. A Pure Line Method of Corn Breeding. Am. Breed Assoc. Rept., 5:51-59. In: SPRAGUE, G.F., 1955. Corn and Corn Improvement. New York, Acad. Press Inc. Publ., cap.5, p.234.

SILVA, W.J., 1970. Híbridos Crípticos em Populações Melhoradas de Milho. Anais da VIII Reunião Brasileira do MiZho. Porto Alegre. P.44-46.

SPRAGUE, G.F., 1939. An Estimation of the Number of Top-crossed Plants Required for Adequate Representation of a Corn Variety. Journal of the American Society of Agronomy. Washington, 3I:II-16.

SPRAGUE, G.F. e TATUM, L.A., 1942. General vs Specific Combining Ability in Singles Crosses of Corn. Agronomy Journal. Washington, 34:923-932. 
SPRAGUE, G.F., 1946. Early Testing of Inbred Lines of Corn. Journal of the American Society of Agronomy. Washington, $38: 108-117$.

SPRAGUE, G.F., 1955. Corn and Corn Improvement. New York, Acad. Press Inc. Publ. P.

STADLER, L.J., 1944. Gamete Selection in Corn Breeding. Journal of the American Society of Agronomy. Washington, $36: 988-989$.

VIEGAS, G.P., 1966. Técnica Cultural. In: CuZtura e Adubacão do Mitho. São Paulo, Inst. Bras. Potassa, cap.9, P. 263-281.

WILLIAMS, J.C.; PENNY, L.H. e SPRAGUE, G.F., 1965. Full-Sib and Half-Sib Estimates of Genetic Variance in a Open-Pollinated Variety of Corn Zea mays L. Crop Science. Madi$\operatorname{son}, 5(2): 125-129$.

ZINSLY, J.R., 1977. O Emprego de Progēnies de Irmãos Germanos obtidas de Plantas Prolíficas para a Obtenção de Híbridos de Milho lZea mays L.). Piracicaba, ESALQ/USP. 63p. (Tese de Livre-Docência).

ZUBER, M.S., 1942. Relative Efficiency of Incomplete Block Designs Using Corn Uniformity Trial Data. Journal of the American Society of Agronomy. Washington, 34:30-47. 
.72 .

10. APẼNDICE

10.1. Tabelas 
Tabela 01 - Análise da variáncia da produção de grãos em $\mathrm{kg} / 10 \mathrm{~m}^{2}$ corrigidos para $15,5 \%$ de umidade do experimento I, em látice simples duplicado $10 \times 10$. So $\times S_{0}$. Piracicaba, $1975 / 76$.

Fontes de variação

Repetições

Tratamentos ( $n a ̃ o$ ajustados)

Blocos D. Rep. Ajustados

Componente $A$

Componente $B$

Erro intra-blocos

Total

Tratamentos (ajustados)

H. crípticos (ajustados)

Testemunhas (ajustados)

H. cripticos vs. testemunhas
G.L.

Q.M.

$\begin{array}{ll}\text { 3. } & 0,9427 \mathrm{n.s} . \\ 99 . & 2,0550 * \star \\ 36 . & 1,2634 * \\ 18 . & \\ 18 . & 0,6833 \\ 261 . & \end{array}$

399.

$\begin{aligned} 99 . & 2,0786 * \star \\ 94 . & 2,0827 * \star \\ 4 . & 1,1468 \mathrm{n.s} . \\ 1 . & 5,4168 * \star\end{aligned}$

Média geral

$=5.345 \mathrm{~kg} / \mathrm{ha}$

C.V. (Iátice) $=15,97 \%$

Média dos H. Crípticos

$=5.371 \mathrm{~kg} / \mathrm{ha}$

Efic. látice $=103,49 \%$

Média dos H. Crípticos selec. $=5.861 \mathrm{~kg} / \mathrm{ha}$

C.V. genético $=10,83 \%$

Erro efetivo (látice)

$=0,7282$

fator de ajuste $=0,0361$

* Significativo ao nivel de $5 \%$ de probabilidade.

**Significativo ao nível de $7 \%$ de probabilidade.

n.s. = não significativo. 
Tabela 02 - Análise da variāncia da produção de grãos em $\mathrm{kg} / 10 \mathrm{~m}^{2}$, corrigidos para $15,5 \%$ de umidade do expe rimento II, em lätice triplo $8 \times 8 . S_{0} \times S_{0}, P i$ racicaba, $1975 / 76$.

\begin{tabular}{|c|c|c|}
\hline Fontes de variação & & Q.M. \\
\hline \multicolumn{2}{|l|}{ Repetições } & 0,1566 n.s. \\
\hline \multicolumn{2}{|l|}{ Tratamentos (não ajustados) } & $2,3073 * \star$ \\
\hline \multicolumn{2}{|l|}{ Blocos D. Rep. Ajustados } & $0,8093 * \star$ \\
\hline \multicolumn{2}{|l|}{ Erro intra-blocos } & 0,2034 \\
\hline \multicolumn{2}{|l|}{ Total } & 191 \\
\hline \multicolumn{2}{|l|}{ Tratamentos (ajustados) } & $2,5450 * \star$ \\
\hline \multicolumn{2}{|l|}{ H. crípticos (ajustados) } & $2,6565 * \star$ \\
\hline \multicolumn{2}{|l|}{ Testemunhas (ajustados) } & $0,9415 * \star$ \\
\hline \multicolumn{2}{|c|}{ H. crípticos vs. testemunhas } & $2,4906 * *$ \\
\hline Média geral & $=5.755 \mathrm{~kg} / \mathrm{ha}$ & C.V. ( lätice $)=$ \\
\hline Média dos H. Crípticos & $=5.818 \mathrm{~kg} / \mathrm{ha}$ & Efic. látice $=133,04 \%$ \\
\hline Média dos H. Crípticos selec. & $=6.986 \mathrm{~kg} / \mathrm{ha}$ & C.V. genético $=13,91 \%$ \\
\hline Erro efetivo (látice) & $=0,2288$ & fator de ajuste $=0,0467$ \\
\hline
\end{tabular}

**Significativo ao nível de $1 \%$ de probabilidade.

n.s. = não significativo. 
Tabela 03 - Análise da variáncia da produção de gräos em $\mathrm{kg} / 10 \mathrm{~m}^{2}$ corrigidos para $15,5 \%$ de umidade do experimento III, em. blocos ao acaso com duas repetições. So $\quad$ So. Piracicaba, $1975 / 76$.

Fontes de variaçãó

Entre repetições

Entre tratamentos

H. crípticos

Testemunhas

H. crípticos vs. testemunhas

Residuo
G.L.

1.

26 .

21.

4.

1 .

26 .
$Q \cdot M$.

53.
Total

Média geral

Média dos H. Crípticos

$$
\begin{aligned}
& =5.560 \mathrm{~kg} / \mathrm{ha} \\
& =5.682 \mathrm{~kg} / \mathrm{ha}
\end{aligned}
$$$$
\text { Média dos H. Crípticos seilec. }=6.239 \mathrm{~kg} / \mathrm{ha}
$$

C.V.

$=15,00 \%$

C.V. genético $=8,30 \%$

*Significativo ao nível de $5 \%$ de probabilidade.

n.s. = não significativo. 
Tabela 04 - Análise da variancia para o caráter índice de espigas por planta, dos experimentos I, II e III, analisados como blocos ao acaso. So $S_{0}$. Piraci caba, $1975 / 76$.

\begin{tabular}{|c|c|c|c|c|c|c|}
\hline \multirow{2}{*}{$\begin{array}{c}\text { Fontes de } \\
\text { variação }\end{array}$} & \multicolumn{2}{|c|}{ Exp. I } & \multicolumn{2}{|c|}{ Exp. II } & \multicolumn{2}{|c|}{ Exp. III } \\
\hline & G.L. & Q.M. & G.L. & Q.M. & G.L. & Q.M. \\
\hline E. repetições & 3. & 0,0180 ns & 2. & $0,0053 \mathrm{~ns}$ & 1. & 0,0167 ns \\
\hline E. tratamentos & 99. & $0,0298 *$ & 63 & $0,0482 * \star$ & 26 & $0,0720 \mathrm{~ns}$ \\
\hline H. crípticos & 94. & $0,0296 *$ & 58. & $0,0469 * \star$ & 21 & 0,0549 ns \\
\hline Testemunhas & 4. & 0,0097 ns & 4. & 0,0057 ns & 4 & 0,0040 ns \\
\hline H. crípticos vs. test. & 1. & $0,1308 * *$ & 1. & $0,2889 * \star$ & 1 & $0,7037 * \star$ \\
\hline Resíduo & 297. & 0,0176 & 126. & 0,0135 & 26. & 0,0401 \\
\hline $\bar{x}$ geral & & 1,04 & & 1,03 & & 0,96 \\
\hline C.V. & & $12,71 \%$ & & $10,55 \%$ & & $17,78 \%$ \\
\hline $\bar{X}_{H . C .}$ & & 1,05 & & 1,11 & & 1,18 \\
\hline $\bar{X}_{H . C .}$ sel. $=$ & & 1,08 & & 1,22 & & 1,18 \\
\hline C.V. Gen. = & & $5,07 \%$ & & $8,64 \%$ & & $7,29 \%$ \\
\hline
\end{tabular}

* Significativo ao nível de $5 \%$ de probabilidade. **Significativo ao nível de $1 \%$ de probabilidade. n.s. = não significativo. 
Tabela 05 - Rendimento em grãos (kg/ha) dos 95 cruzamentos $\mathrm{S}_{0} \times \mathrm{S}_{0}$ e das testemunhas, correspondentes ao experimento I, corrigidos para umidade de $15,5 \%$ e "stand" de 50 plantas por parcela. Produção em por centagem da média das testemunhas Ag-152 R e Centralmex. Valores médios do caráter índice de espi gas por planta. Piracicaba, $1975 / 76$.

\begin{tabular}{ll}
\hline$N^{8}$ de & Identifi- \\
ordem caço da \\
progẽnie
\end{tabular}

$\frac{\text { Produção de grãos }}{\text { kg/ha }} \begin{gathered}\text { test } \\ \text { tédia }\end{gathered}$
Indice de espigas/ planta

\begin{tabular}{|c|c|c|c|c|}
\hline 1 & 81 & 7167 & 154,13 & 1,17 \\
\hline 2 & 49 & 6860 & 147,53 & 1,28 \\
\hline 3 & 44 & 6472 & 139,18 & 1,26 \\
\hline 4 & 54 & 6332 & 136,17 & 1,18 \\
\hline 5 & 39 & 6323 & 135,98 & 1,00 \\
\hline 6 & 24 & 6306 & 135,61 & 1,20 \\
\hline 7 & 55 & 6303 & 135,55 & 1,14 \\
\hline 8 & 80 & 6297 & 135,42 & 1,01 \\
\hline 9 & 56 & 6257 & 134,56 & 1,04 \\
\hline 10 & 69 & 6209 & 133,53 & 1,08 \\
\hline 11 & 42 & 6205 & 133,44 & 1,02 \\
\hline 12 & 40 & 6106 & 131,31 & 1,04 \\
\hline 13 & 03 & 6055 & 130,22 & 1,03 \\
\hline 14 & 89 & 6053 & 130,17 & 1,09 \\
\hline 15 & 94 & 6034 & 129,76 & 1,10 \\
\hline 16 & 71 & 6033 & 129,74 & 1,12 \\
\hline 17 & 93 & 5971 & 128,41 & 1,00 \\
\hline 18 & 67 & 5936 & 127,66 & 1,07 \\
\hline 19 & 27 & 5922 & 127,35 & 1,01 \\
\hline 20 & 70 & 5875 & 126,34 & 0,96 \\
\hline 21 & 08 & 5870 & 126,24 & 1,10 \\
\hline 22 & 83 & 5850 & 125,81 & 1,20 \\
\hline
\end{tabular}


Tabela 05 (Continuação)

\begin{tabular}{|c|c|c|c|c|}
\hline \multirow{2}{*}{$\begin{array}{l}N^{8} \text { de } \\
\text { ordem }\end{array}$} & \multirow{2}{*}{$\begin{array}{l}\text { Identifi- } \\
\text { cação da } \\
\text { progẽnie }\end{array}$} & Produção & te grãos & \multirow{2}{*}{$\begin{array}{c}\text { Indice de } \\
\text { espigas } \\
\text { planta }\end{array}$} \\
\hline & & $\mathrm{kg} / \mathrm{ha}$ & $\begin{array}{c}\text { Rel. média } \\
\text { test. }\end{array}$ & \\
\hline
\end{tabular}

\begin{tabular}{|c|c|c|c|c|}
\hline 23 & 84 & 5807 & 124,88 & 1,19 \\
\hline 24 & 59 & 5758 & 123,83 & 1,05 \\
\hline 25 & 48 & 5737 & 123,38 & 0,96 \\
\hline 26 & 17 & 5728 & 123,18 & 1,08 \\
\hline 27 & 33 & 5680 & 122,15 & 0,99 \\
\hline 28 & 74 & 5663 & 121,78 & 1,07 \\
\hline 29 & 13 & 5634 & 121,16 & 1,15 \\
\hline 30 & 60 & 5618 & 120,82 & 1,04 \\
\hline 31 & 31 & 5616 & 120,77 & 0,94 \\
\hline 32 & 01 & 5573 & 119,85 & 1,16 \\
\hline 33 & 64 & 5560 & 119,57 & 1,12 \\
\hline 34 & 61 & 5552 & 119,48 & $.0,88$ \\
\hline 35 & 11 & 5520 & 118,71 & 1,02 \\
\hline 36 & 07 & 5507 & 118,43 & 1,06 \\
\hline 37 & 29 & 5493 & 118,13 & 1,14 \\
\hline 38 & 65 & 5472 & 117,68 & 1,03 \\
\hline 39 & 16 & 5471 & 117,66 & 1,06 \\
\hline 40 & 91 & 5452 & 117,25 & 1,19 \\
\hline 41 & 79 & 5444 & 117,08 & 1,04 \\
\hline 42 & 92 & 5435 & 116,88 & 0,97 \\
\hline 43 & 68 & 5395 & 116,02 & 1,08 \\
\hline 44 & 86 & 5365 & 115,38 & 1,14 \\
\hline 45 & 73 & 5354 & $-115,14$ & 1,11 \\
\hline 46 & 32 & 5347 & 114,99 & 0,98 \\
\hline 47 & 04 & 5343 & 114,90 & 1,09 \\
\hline 48 & 02 & 5336 & 114,75 & 1,01 \\
\hline 49 & 10 & 5335 & 114,73 & 1,04 \\
\hline 50 & 43 & 5331 & 114,65 & 1,16 \\
\hline
\end{tabular}


Tabela 05 (Continuação)

\begin{tabular}{|c|c|c|c|c|}
\hline \multirow{2}{*}{$\begin{array}{l}N^{8} \text { de } \\
\text { ordem }\end{array}$} & \multirow{2}{*}{$\begin{array}{l}\text { Identifi- } \\
\text { cação da } \\
\text { progẽnie }\end{array}$} & \multicolumn{2}{|c|}{ Produção de grãos } & \multirow{2}{*}{$\begin{array}{c}\text { Indice de } \\
\text { espigas/ } \\
\text { planta }\end{array}$} \\
\hline & & kg/ha & $\begin{array}{c}\text { Rel. média } \\
\text { test. }\end{array}$ & \\
\hline 51 & 37 & 5330 & 114,62 & 0,94 \\
\hline 52 & 46 & 5311 & 114,22 & 1,04 \\
\hline 53 & 90 & 5306 & 114,11 & 1,08 \\
\hline 54 & 25 & 5293 & 113,83 & 0,99 \\
\hline 55 & 51 & 5291 & 113,78 & 0,97 \\
\hline 56 & 38 & 5290 & 113,76 & 1,02 \\
\hline 57 & 50 & 5248 & 112,86 & 1,04 \\
\hline 58 & 63 & 5231 & 112,49 & 1,04 \\
\hline 59 & 14 & 5225 & 112,37 & 1,03 \\
\hline 60 & 72 & 5217 & 112,19 & 1,15 \\
\hline 61 & 77 & 5201 & 111,85 & 1,08 \\
\hline 62 & 62 & 5198 & 111,78 & 0,96 \\
\hline 63 & 28 & 5177 & 111,33 & 1,15 \\
\hline 64 & 15 & 5160 & 110,97 & 0,96 \\
\hline 65 & 19 & 5155 & 110,86 & 0,96 \\
\hline 66 & 66 & 5149 & 110,73 & 1,08 \\
\hline 67 & 18 & 5136 & 110,45 & 0,98 \\
\hline 68 & 22 & 5132 & 110,37 & 1,04 \\
\hline 69 & 41 & 5123 & 110,17 & 0,93 \\
\hline 70 & 06 & 5119 & 110,09 & 1,01 \\
\hline 71 & 76 & 5097 & 109,61 & 1,17 \\
\hline 72 & 82 & 5071 & 109,05 & 1.05 \\
\hline 73 & 45 & 5067 & 108,97 & 1,09 \\
\hline 74 & 78 & 5054 & 108,69 & 1,08 \\
\hline 75 & 87 & 5054 & 108,69 & 1,05 \\
\hline 76 & 21 & 5044 & 108,47 & 1,00 \\
\hline 77 & 52 & 5044 & 108,47 & 1,14 \\
\hline 78 & 05 & 4988 & 107,27 & 0,97 \\
\hline
\end{tabular}


Tabela 05 (Continuação)

\begin{tabular}{|c|c|c|c|c|}
\hline \multirow{2}{*}{$\begin{array}{l}N^{8} \text { de } \\
\text { ordem }\end{array}$} & \multirow{2}{*}{$\begin{array}{l}\text { Identifi- } \\
\text { cação da } \\
\text { progênie }\end{array}$} & \multicolumn{2}{|c|}{ Produção de grãos } & \multirow{2}{*}{$\begin{array}{c}\text { Indice de } \\
\text { espigas/ } \\
\text { planta }\end{array}$} \\
\hline & & kg/ha & $\begin{array}{c}\text { Rel. média } \\
\text { test. }\end{array}$ & \\
\hline 79 & 95 & 4972 & 106,92 & 0,98 \\
\hline 80 & 12 & 4928 & 105,98 & 0,95 \\
\hline 81 & 88 & 4921 & 105,83 & 1,00 \\
\hline 82 & 20 & 4877 & 104,88 & 0,96 \\
\hline 83 & 57 & 4858 & 104,47 & 1,06 \\
\hline 84 & 35 & 4853 & 104,37 & 0,96 \\
\hline 85 & 09 & 4769 & 102,56 & 1,05 \\
\hline 86 & 23 & 4734 & 101,81 & 0,98 \\
\hline 87 & 30 & 4709 & 101,27 & 0,91 \\
\hline 88 & 36 & 4706 & 101,20 & 1,03 \\
\hline 89 & 53 & 4605 & 99,03 & 1,04 \\
\hline 90 & 58 & 4515 & 97,10 & 1,16 \\
\hline 91 & 26 & 4481 & 96,37 & 0,94 \\
\hline 92 & 34 & 4253 & 91,46 & 0,91 \\
\hline 93 & 75 & 4108 & 88,34 & 0,89 \\
\hline 94 & 47 & 2549 & 54,82 & 0,90 \\
\hline 95 & 85 & 1748 & 37,59 & 0,85 \\
\hline 96 & Composto A & 4192 & 90,15 & 0,96 \\
\hline 97 & Composto B & 5224 & 112,34 & 1,00 \\
\hline 98 & $A \times B \quad(F)$, & 5470 & 117,63 & 1,00 \\
\hline 99. & Centralmex & 4415 & 94,95 & 0,88 \\
\hline 100 & $A g-152 R$ & 4885 & 105,05 & 0,98 \\
\hline
\end{tabular}

Média geral . . . . . . . . . . $5.345 \mathrm{~kg} / \mathrm{ha}$ Média dos híbridos crípticos. . . . . . . . $5.371 \mathrm{~kg} / \mathrm{ha}$ Média das testemunhas (Ag-152 R e Centralmex) . $4.650 \mathrm{~kg} / \mathrm{ha}$ Média geral do Índice de espigas por planta . . 1,04. 
.81.

Tabela 06 - Rendimento em grãos (kg/ha) dos 59 cruzamentos $S_{0} \times S_{0}$ e das testemunhas, correspondentes a expe rimento II, corrigidos para umidade de $15,5 \%$ e "stand" de 50 plantas por parcela. Produção em poI centagem da média das testemunhas Ag-152 R e Centralmex. Valores médios do caráter índice de espi gas por planta. Piracicaba, $1975 / 76$.

\begin{tabular}{|c|c|c|c|}
\hline \multirow{2}{*}{$\begin{array}{l}\text { N: de } \\
\text { ordem }\end{array}$} & \multirow{2}{*}{$\begin{array}{l}\text { Identifi- } \\
\text { cação da } \\
\text { progēnie }\end{array}$} & Produção de grãos & \multirow{2}{*}{$\begin{array}{c}\text { Indice de } \\
\text { espigas/ } \\
\text { planta }\end{array}$} \\
\hline & & $\begin{array}{c}\text { Rel. média } \\
\text { test. }\end{array}$ & \\
\hline
\end{tabular}

\begin{tabular}{|c|c|c|c|c|}
\hline 1 & 145 & 9719 & 177,94 & 1,19 \\
\hline 2 & 129 & 7268 & 133,06 & 1,32 \\
\hline 3 & 143 & 7079 & 129,60 & 1,27 \\
\hline 4 & 132 & 7052 & 129,11 & 1,18 \\
\hline 5 & 147 & 7050 & 129,07 & 1,24 \\
\hline 6 & 109 & 6994 & 128,05 & 1,23 \\
\hline 7 & 149 & 6850 & 125,41 & 1,18 \\
\hline 8 & 114 & 6789 & 124,30 & 1,22 \\
\hline 9 & 104 & 6615 & 121,11 & 1,12 \\
\hline 10 & 146 & 6562 & 120,14 & 1,23 \\
\hline 11 & 98 & 6536 & 119,66 & 1,30 \\
\hline 12 & 139 & 6501 & 119,02 & 1,13 \\
\hline 13 & 101 & 6448 & 118,05 & 1,24 \\
\hline 14 & 154 & 6340 & 116,07 & 1,18 \\
\hline 15 & 115 & 6232 & 114,10 & 1,22 \\
\hline 16 & 141 & 6221 & 113,90 & 1,62 \\
\hline 17 & 131 & 6159 & 112,76 & 1,06 \\
\hline 18 & 111 & 6135 & 112,32 & 1,18 \\
\hline 19 & 118 & 6099 & 111,66 & 1,09 \\
\hline 20 & 123 & 6046 & 110,69 & 1,06 \\
\hline 21 & 120 & 6041 & 110,60 & 0,97 \\
\hline 22 & 106 & 6006 & 109,96 & 1,13 \\
\hline
\end{tabular}


Tabela 06 (Continuação)

\begin{tabular}{|c|c|c|c|c|}
\hline \multirow{2}{*}{$\begin{array}{l}N^{8} \text { de } \\
\text { ordem }\end{array}$} & \multirow{2}{*}{$\begin{array}{l}\text { Identifi- } \\
\text { cação da } \\
\text { progénie }\end{array}$} & \multicolumn{2}{|c|}{ Produção de grãos } & \multirow{2}{*}{$\begin{array}{c}\text { Indice de } \\
\text { espigas/ } \\
\text { planta }\end{array}$} \\
\hline & & $\mathrm{kg} / \mathrm{ha}$ & $\begin{array}{c}\text { Rel. media } \\
\text { test. }\end{array}$ & \\
\hline 23 & 103 & 5922 & 108,42 & 1,06 \\
\hline 24 & 127 & 5902 & 108,06 & 1,01 \\
\hline 25 & 119 & 5881 & 107,67 & 1,12 \\
\hline 26 & 97 & 5864 & 107,36 & 1,04 \\
\hline 27 & 102 & 5839 & 106,90 & 1,19 \\
\hline 28 & 133 & 5817 & 106,50 & 1,06 \\
\hline 29 & 113 & 5787 & 105,95 & 1,31 \\
\hline 30 & 152 & 5774 & 105,71 & 0,97 \\
\hline 31 & 138 & 5772 & 105,68 & 1,04 \\
\hline 32 & 100 & 5764 & 105,53 & 1,06 \\
\hline 33 & 144 & 5751 & 105,29 & 1,05 \\
\hline 34 & 108 & 5649 & 103,42 & 1,07 \\
\hline 35 & 137 & 5602 & 102,56 & 1,10 \\
\hline 36 & 128 & 5537 & 101,37 & 1,07 \\
\hline 37 & 125 & 5533 & 101,30 & 1,04 \\
\hline 38 & 107 & 5493 & 100,57 & 1,15 \\
\hline 39 & 110 & 5482 & 100,37 & 1,15 \\
\hline 40 & 140 & 5473 & 100,20 & 1,10 \\
\hline 41 & 142 & 5425 & 99,32 & 1,06 \\
\hline 42 & 116 & 5419 & 99,21 & 1,05 \\
\hline 43 & 105 & 5389 & 98,66 & 0,97 \\
\hline 44 & 126 & 5328 & 97,55 & 1,07 \\
\hline 45 & 130 & 5240 & 95,94 & 1,13 \\
\hline 46 & 117 & 5234 & 95,83 & 1,09 \\
\hline 47 & 99 & 5185 & 94,93 & 0,96 \\
\hline 48 & 151 & 5152 & 94,32 & 0,99 \\
\hline 49 & 136 & 5127 & 93,87 & 1,17 \\
\hline
\end{tabular}


Tabela 06 (Continuação)

\begin{tabular}{|c|c|c|c|c|}
\hline \multirow{2}{*}{$\begin{array}{l}N^{8} \text { de } \\
\text { ordem }\end{array}$} & \multirow{2}{*}{$\begin{array}{l}\text { Identifi- } \\
\text { cação da } \\
\text { progénie }\end{array}$} & \multicolumn{2}{|c|}{ Produção de grãos } & \multirow{2}{*}{$\begin{array}{c}\text { Indice de } \\
\text { espigas/ } \\
\text { planta }\end{array}$} \\
\hline & & $\mathrm{kg} / \mathrm{ha}$ & $\begin{array}{c}\text { Rel.media } \\
\text { test. }\end{array}$ & \\
\hline 50 & 135 & 5117 & 93,68 & 0,98 \\
\hline 51 & 148 & 5085 & 93,10 & 1,15 \\
\hline 52 & 150 & 5084 & 93,08 & 0,97 \\
\hline 53 & 124 & 5053 & 92,51 & 0,89 \\
\hline 54 & 112 & 4970 & 90,99 & 1,22 \\
\hline 55 & 134 & 4712 & 86,27 & 1,03 \\
\hline 56 & 122 & 4680 & 85,68 & 0,86 \\
\hline 57 & 96 & 4646 & 85,06 & 1,06 \\
\hline 58 & 121 & 4063 & 74,39 & 1,15 \\
\hline 59 & 153 & 2781 & 50,92 & 0,86 \\
\hline 60 & Composto $A$ & 5158 & 94,62 & 1,01 \\
\hline 61 & Composto B & 5627 & 103,02 & 0,96 \\
\hline 62 & $A \times B\left(F_{7}\right)$ & 5251 & 96,14 & 1,01 \\
\hline 63 & Centralmex & 4713 & 86,29 & 0,91 \\
\hline 64 & $A g-152 R$ & 6210 & 113,69 & 0,95 \\
\hline
\end{tabular}

Média geral . . . . . . . . . . $5.755 \mathrm{~kg} / \mathrm{ha}$ Média dos híbridos crípticos. ...... . $5.818 \mathrm{~kg} / \mathrm{ha}$ Média das testemunhas ( $\mathrm{Ag}-152 \mathrm{R}$ e Centralmex).. $5.462 \mathrm{~kg} / \mathrm{ha}$ Média geral do índice de espigas por planta.. 1,03 
Tabela 07 - Rendimento em grãos (kg/ha) dos 22 cruzamentos $S_{0} \times S_{0}$ e das testemunhas, correspondentes ao expe rimento III, corrigidos para umidade de $15,5 \%$ e "stand" de 50 plantas por parcela. Produção em por centagem da média das testemunhas Ag-152 R e Centralmex. Valores médios do caräter índice de espi gas por planta. Piracicaba, 1975/76.

\begin{tabular}{ll}
\hline$N^{8}$ de & Identifi- \\
ordem & cação da \\
& Progénie
\end{tabular}

$\frac{\text { Produção de grãos }}{\text { kg/ha }} \frac{\operatorname{Rel} \text { média }}{\text { test. }}$
Indice de espigas/ planta

\begin{tabular}{|c|c|c|c|c|}
\hline 1 & 157 & 8358 & 170,64 & 1,32 \\
\hline 2 & 155 & 6206 & 126,70 & 1,32 \\
\hline 3 & 166 & 6206 & 126,70 & 1,37 \\
\hline 4 & 159 & 6144 & 125,44 & 0,92 \\
\hline 5 & 164 & 6017 & 122,85 & 1,15 \\
\hline 6 & 174 & 6013 & 122,76 & 1,31 \\
\hline 7 & 176 & 6013 & 122,76 & 1,07 \\
\hline 8 & 169 & 5927 & 121,01 & 1,28 \\
\hline 9 & 165 & 5848 & 119,40 & 1,10 \\
\hline 10 & 162 & 5660 & 115,56 & 0,96 \\
\hline 11 & 171 & 5620 & 114,74 & 1,34 \\
\hline 12 & 173 & 5586 & 114,05 & 1,55 \\
\hline 13 & 170 & 5577 & 113,86 & 1,37 \\
\hline 14 & 163 & 5443 & 111,13 & 1.07 \\
\hline 15 & 168 & 5277 & 107,74 & 0,97 \\
\hline 16 & 158 & 5260 & 107,39 & 1,08 \\
\hline 17 & 156 & 5200 & 106,17 & 1,20 \\
\hline 18 & 161 & 5196 & 106,08 & 1,22 \\
\hline 19 & 175 & 5051 & 103,12 & 1,25 \\
\hline 20 & 172 & 4947 & 101,00 & 1,08 \\
\hline 21 & 160 & 4892 & 99,88 & 1,11 \\
\hline 22 & 167 & 4568 & 93,26 & 0,95 \\
\hline
\end{tabular}


Tabela 07 (Continuação)

\begin{tabular}{|c|c|c|c|c|}
\hline \multirow{2}{*}{$\begin{array}{l}\text { No de } \\
\text { ordem }\end{array}$} & \multirow{2}{*}{$\begin{array}{l}\text { Identifi- } \\
\text { cação da } \\
\text { progênie }\end{array}$} & \multicolumn{2}{|c|}{ Produção de grãos } & \multirow{2}{*}{$\begin{array}{c}\text { Indice de } \\
\text { espigas/ } \\
\text { planta }\end{array}$} \\
\hline & & $\mathrm{kg} / \mathrm{ha}$ & $\begin{array}{c}\text { Rel. média } \\
\text { test. }\end{array}$ & \\
\hline & & & & \\
\hline 23 & Composto $A$ & 5199 & 106,15 & 0,93 \\
\hline 24 & Composto $B$ & 4507 & 92,02 & 0,90 \\
\hline 25 & $A \times B\left(F_{7}\right)$ & 5623 & 114,80 & 0,82 \\
\hline 26 & Centralmex & 5235 & 106,88 & 0,92 \\
\hline 27 & $\mathrm{Ag}-152 \mathrm{R}$ & 4561 & 93,12 & 0,86 \\
\hline
\end{tabular}

Média geral . . . . . . . . . . . . $5.560 \mathrm{~kg} / \mathrm{ha}$ Média dos híbridos crípticos . . . . . . . $5.682 \mathrm{~kg} / \mathrm{ha}$ Média das testemunhas (Ag-152 e Centralmex). . $4.898 \mathrm{~kg} / \mathrm{ha}$ Média geral do indice de espigas por planta. . 0,96 
.86.

Tabela 08 - Relação dos 70 cruzamentos $S_{0} \times S_{0}$ selecionados nos experimentos I, II e III. Peso de grãos em kg/ha, corrigidos para $15,5 \%$ de umidade e "stand" ideal de 50 plantas por parcela, porcentagem em relação à média das testemunhas Ag-152 R e centralmex e o Indice de espigas por planta. Piracicaba, 1975/76.

\begin{tabular}{|c|c|c|c|c|c|}
\hline \multirow{2}{*}{$\begin{array}{l}N^{8} \text { de } \\
\text { ordem }\end{array}$} & \multirow{2}{*}{$\begin{array}{l}\text { N do ex- }^{\text {dorimento }}\end{array}$} & \multirow{2}{*}{$\begin{array}{l}\text { Identifi- } \\
\text { cação da } \\
\text { progênie }\end{array}$} & \multirow{2}{*}{$\frac{\text { Produção }}{k g / h a}$} & \multirow{2}{*}{ 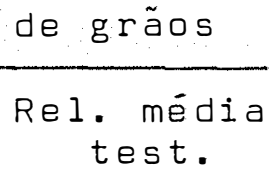 } & \multirow{2}{*}{$\begin{array}{c}\text { Indice de } \\
\text { espigas/ } \\
\text { planta }\end{array}$} \\
\hline & & & & & \\
\hline 1 & I I & 145 & 9719 & 177,94 & 1,19 \\
\hline 2 & I I I & 157 & 8358 & 170,64 & 1,32 \\
\hline 3 & I & 81 & 7167 & 154,13 & 1,17 \\
\hline 4 & I & 49 & 6860 & 147,53 & 1,28 \\
\hline 5 & I & 44 & 6472 & 139,18 & 1,26 \\
\hline 6 & I & 54 & 6332 & 136,17 & 1,18 \\
\hline 7 & I & 39 & 6323 & 135,98 & 1,00 \\
\hline 8 & I & 24 & 6306 & 135,61 & 1,20 \\
\hline 9 & I & 55 & 6303 & 135,55 & 1,14 \\
\hline 10 & I & 80 & 6297 & 135,42 & 1,01 \\
\hline 11 & I & 56 & 6257 & 134,56 & 1,04 \\
\hline 12 & I & 69 & 6209 & 133,53 & 1,08 \\
\hline 13 & I & 42 & 6205 & 133,44 & 1,02 \\
\hline 14 & I I & 129 & 7268 & 133,06 & 1,32 \\
\hline 15 & I & 40 & 6106 & 131,31 & 1,04 \\
\hline 16 & I & 03 & 6055 & 130,22 & 1,03 \\
\hline 17 & I & 89 & 6053 & 130,17 & 1,09 \\
\hline 18 & I & 94 & 60.34 & 129,76 & 1,10 \\
\hline 19 & I & 71 & 6033 & 129.74 & 1,12 \\
\hline 20 & I I & 143 & 7079 & 129,26 & 1,27 \\
\hline 21 & I I & 132 & 7052 & 129,11 & 1,18 \\
\hline 22 & I I & 147 & 7050 & 129,07 & 1,24 \\
\hline
\end{tabular}


Tabela 08 (Continuação)

\begin{tabular}{|c|c|c|c|c|c|}
\hline \multirow{2}{*}{$\begin{array}{l}N^{8} \text { de } \\
\text { ordem }\end{array}$} & \multirow{2}{*}{$\begin{array}{l}\text { No do ex- } \\
\text { perimento }\end{array}$} & \multirow{2}{*}{$\begin{array}{l}\text { Identifi- } \\
\text { caçäo da } \\
\text { progênie }\end{array}$} & \multicolumn{2}{|c|}{ Produção de grãos } & \multirow{2}{*}{$\begin{array}{c}\text { Indice de } \\
\text { espigas } \\
\text { planta }\end{array}$} \\
\hline & & & $\mathrm{kg} / \mathrm{ha}$ & $\begin{array}{c}\text { Rel. média } \\
\text { test. }\end{array}$ & \\
\hline & & . & & & \\
\hline 23 & I & 93 & 5971 & $.128,41$ & 1,00 \\
\hline 24 & I I & 109 & 6994 & 128,05 & 1,23 \\
\hline 25 & I & 67 & 5936 & 127,66 & 1,07 \\
\hline 26 & I & 27 & 5922 & 127,35 & 1,01 \\
\hline 27 & I I I & 155 & 6206 & 126,70 & 1,32 \\
\hline 28 & I I I & 166 & 6206 & 126,70 & 1,37 \\
\hline 29 & I & $\cdot 70$ & 5875 & 126,34 & 0,96 \\
\hline 30 & I & 08 & 5870 & 126,24 & 1,10 \\
\hline 31 & I & 83 & 5850 & 125,81 & 1,20 \\
\hline 32 & I I I & 159 & 6144 & 125,44 & 0,92 \\
\hline 33 & I I & 149 & 6850 & 125,41 & 1,18 \\
\hline 34 & I & 84 & 5807 & 124,88 & 1,19 \\
\hline 35 & I I & 114 & 6789 & 124,30 & 1,22 \\
\hline 36 & I & 59 & 5758 & 123,83 & 1,05 \\
\hline 37 & I & 48 & 5737 & 123,38 & 0,96 \\
\hline 38 & I & 17 & 5728 & 123,18 & 1,08 \\
\hline 39 & I I I & 164 & 6017 & 122,85 & 1,15 \\
\hline 40 & I I I & 174 & 6013 & 122,76 & 1,31 \\
\hline 41 & I I I & 176 & 6013 & 122,76 & 1,07 \\
\hline 42 & I & 33 & 5680 & 122,15 & 0,99 \\
\hline 43 & I & 74 & 5663 & 121,78 & 1,07 \\
\hline 44 & I & 13 & 5634 & 121,16 & 1,15 \\
\hline 45 & I I & 104 & 6615 & 121,11 & 1,12 \\
\hline 46 & I I I & 169 & 5927 & 121,01 & 1,28 \\
\hline 47 & I & 60 & 5618 & 120,82 & 1,04 \\
\hline 48 & I & 31 & 5616 & 120,77 & 0,94 \\
\hline 49 & I I & 146 & 6562 & 120,14 & 1,23 \\
\hline 50 & I & 01 & 5573 & 119,85 & 1,16 \\
\hline
\end{tabular}


Tabela 08 (Continuação)

\begin{tabular}{|c|c|c|c|c|c|}
\hline \multirow{2}{*}{$\begin{array}{l}\text { No de } \\
\text { ordem }\end{array}$} & \multirow{2}{*}{$\begin{array}{l}\text { Ne do ex- } \\
\text { perimento }\end{array}$} & \multirow{2}{*}{$\begin{array}{l}\text { Identifi- } \\
\text { cação da } \\
\text { progenie }\end{array}$} & \multirow{2}{*}{$\frac{\text { Produção }}{k g / h a}$} & \multirow{2}{*}{$\frac{\text { de grãos }}{\text { Rel. média }} \begin{array}{c}\text { test. }\end{array}$} & \multirow{2}{*}{$\begin{array}{c}\text { Indice de } \\
\text { espigas/ } \\
\text { planta }\end{array}$} \\
\hline & & & & & \\
\hline 51 & I I & 98 & 6536 & 119,66 & 1,30 \\
\hline 52 & I & 64 & 5560 & 119,57 & 1,12 \\
\hline 53 & I & 61 & 5552 & 119,40 & 0,88 \\
\hline 54 & I I I & 165 & 5848 & 119,40 & 1,10 \\
\hline 55 & I I & 139 & 6501 & 119,02 & 1,13 \\
\hline 56 & I & 11 & 5520 & 118,71 & 1,02 \\
\hline 57 & I & .07 & 5507 & 118,43 & 1,06 \\
\hline 58 & I & 29 & 5493 & 118,13 & 1,14 \\
\hline 59 & I I & 101 & 6448 & 118,05 & 1,24 \\
\hline 60 & I & 65 & 5472 & 117,68 & 1,03 \\
\hline 61 & I & $16:$ & 5471 & 117,66 & 1,06 \\
\hline 62 & I & 91 & 5452 & 117,25 & 1,19 \\
\hline 63 & I & 79 & 5444 & 117,08 & 1,04 \\
\hline 64 & I & 92 & 5435 & 116,88 & 0,97 \\
\hline 65 & I I & 154 & 6340 & 116,07 & 1,18 \\
\hline 66 & I & 68 & 5395 & 116,02 & 1,08 \\
\hline 67 & I I I & 162 & 5660 & 115,56 & 0,96 \\
\hline 68 & I & 86 & 5365 & 115,38 & 1,14 \\
\hline 69 & I & 73 & 5354 & 115,14 & 1,11 \\
\hline 70 & I & 32 & 5347 & 114,99 & 0,98 \\
\hline
\end{tabular}

Média dos híbridos crípticos selecionados. . . $6.140 \mathrm{~kg} / \mathrm{ha}$ Indice de espigas por planta médio.... . I, . . 16 
.89.

10.2. Figuras 


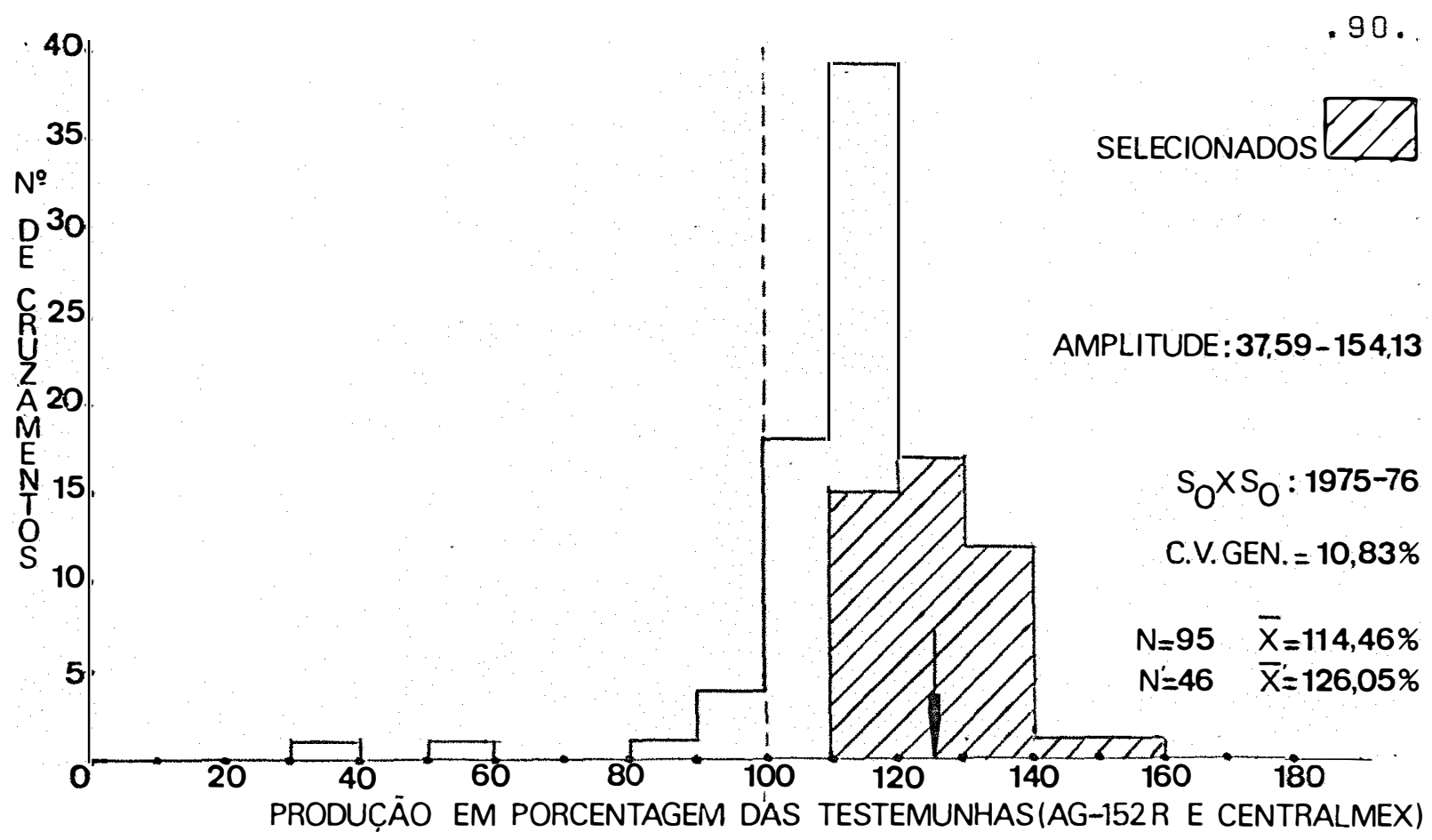

Figura 01 - Distribuição de frequência da produção de grãos corrigidos para $15,5 \%$ de umidade, dos 95 híbridos crípticos correspondentes ao experimento $\mathrm{I}$, expressa em \% das testemunhas $(\mathrm{Ag}-152 \mathrm{R}$ e Centralmex). So $\times$ So. Piracicaba, 1975/76.

A linha tracejada representa a média das testemunhas e a seta, a média dos híbridos sèlecionados.

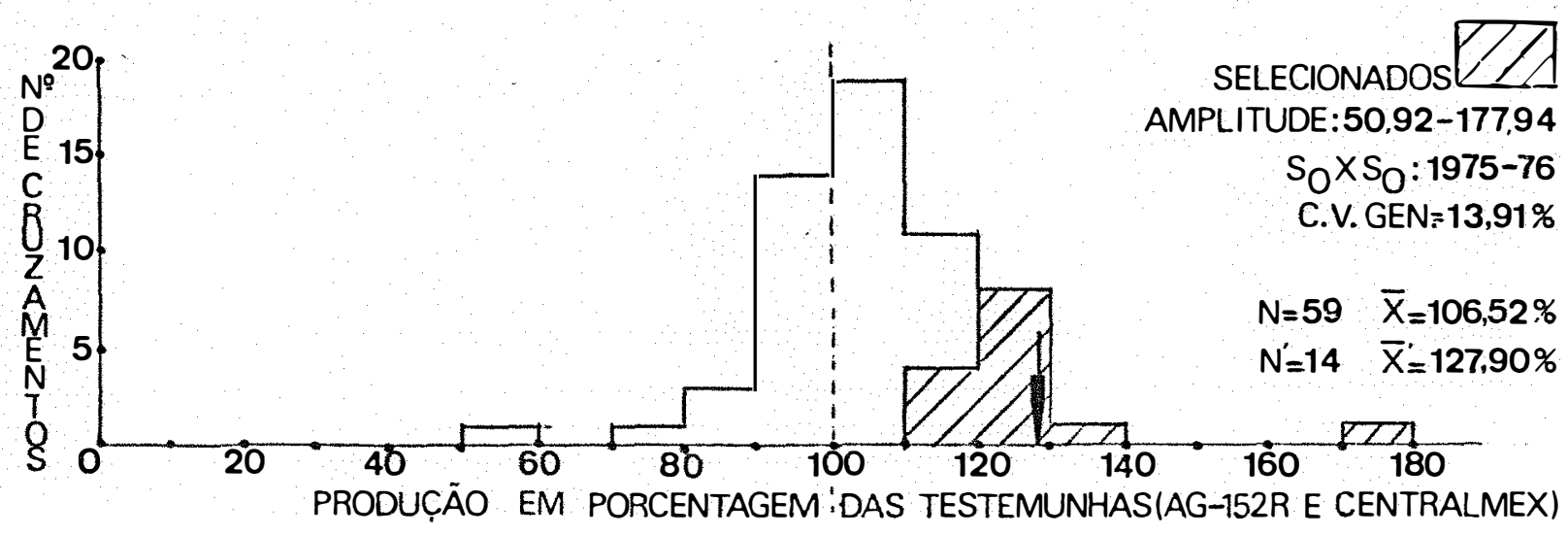

Figura 02 - Distribuição de frequências da produção de grãos corrigidos para $15,5 \%$ de umidade, dos 59 híbridos crípticos correspondentes ao experimento II, expressa em \% das testemunhas ( $\mathrm{Ag}-152 \mathrm{R}$ e Centralmex). $S_{0} \times S_{0}$. Piracicaba, 1975/76.

A linha tracejada representa a média das testemunhas e a seta, a média dos híbridos selecionados. 


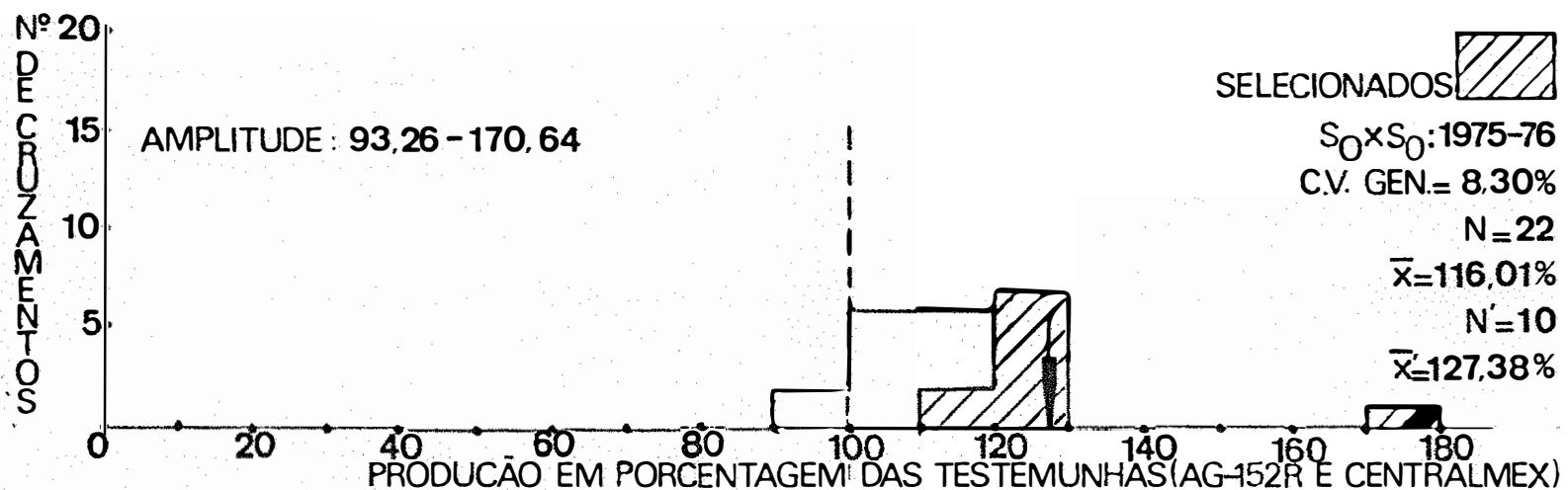

Figura 03 - Distribuição de frequências da produção de grãos, corrigidos para 15,5\% de umidade, dos 22 híbridos crípticos correspondentes ao ex perimento III, expressa em \% das testemunhas (Ag-152 R e Central= mex). So x So. Piracicaba, 1975/76. A Iinha tracejada representa

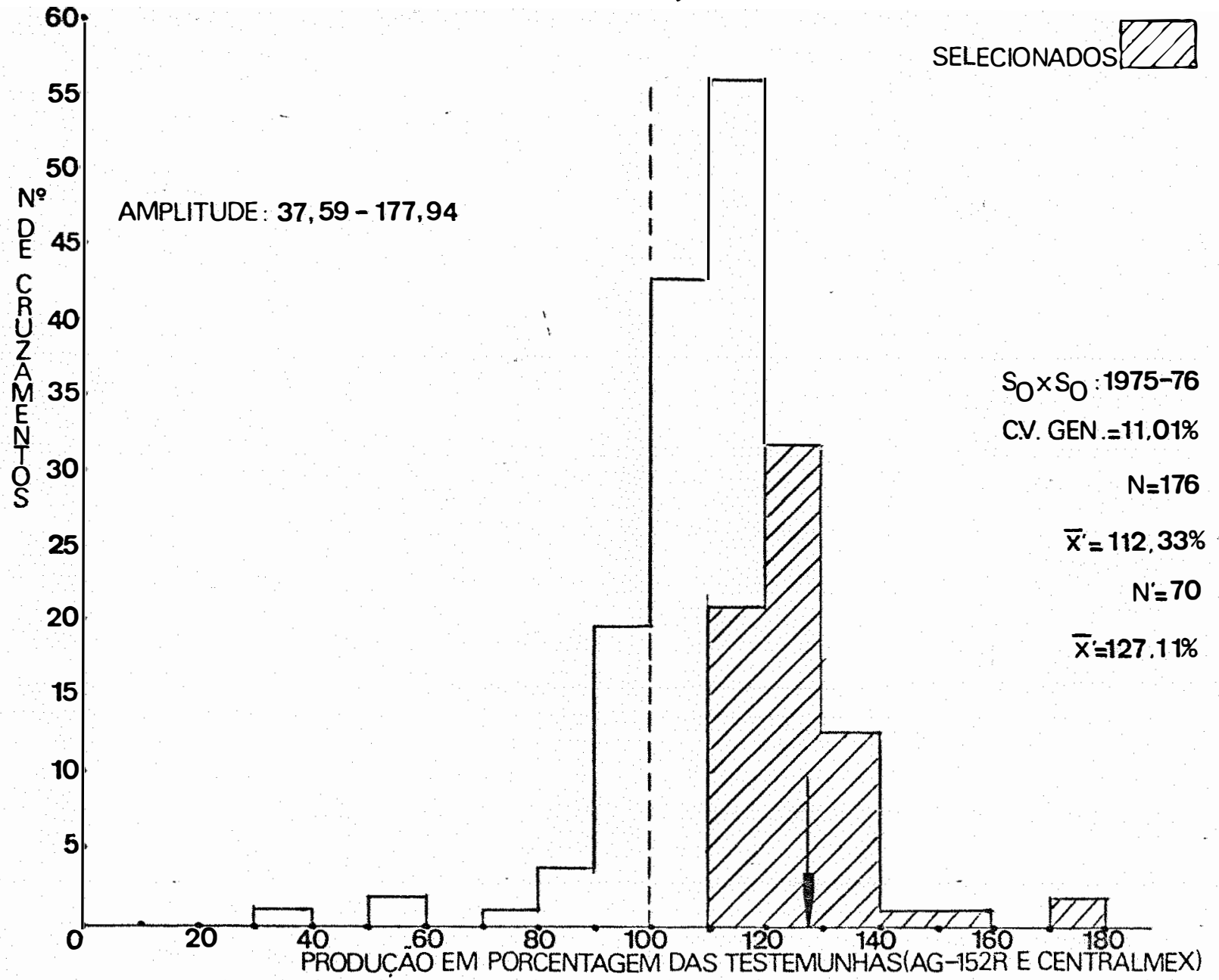

Figura 04 - Distribuição de frequências da produção de grãos, corrigidos para $15,5 \%$ de umidade, dos 176 híbridos crípticos correspondentes aos três experimentos, expressa em \% das testemunhas ( $\mathrm{Ag}-152 \mathrm{R}$ e Centralmex . So $\times S_{0}$. Piracicaba, 1975/76. A linha tracejada representa a média das testemunhas e a seta, a média dos híbridos selecionados. 


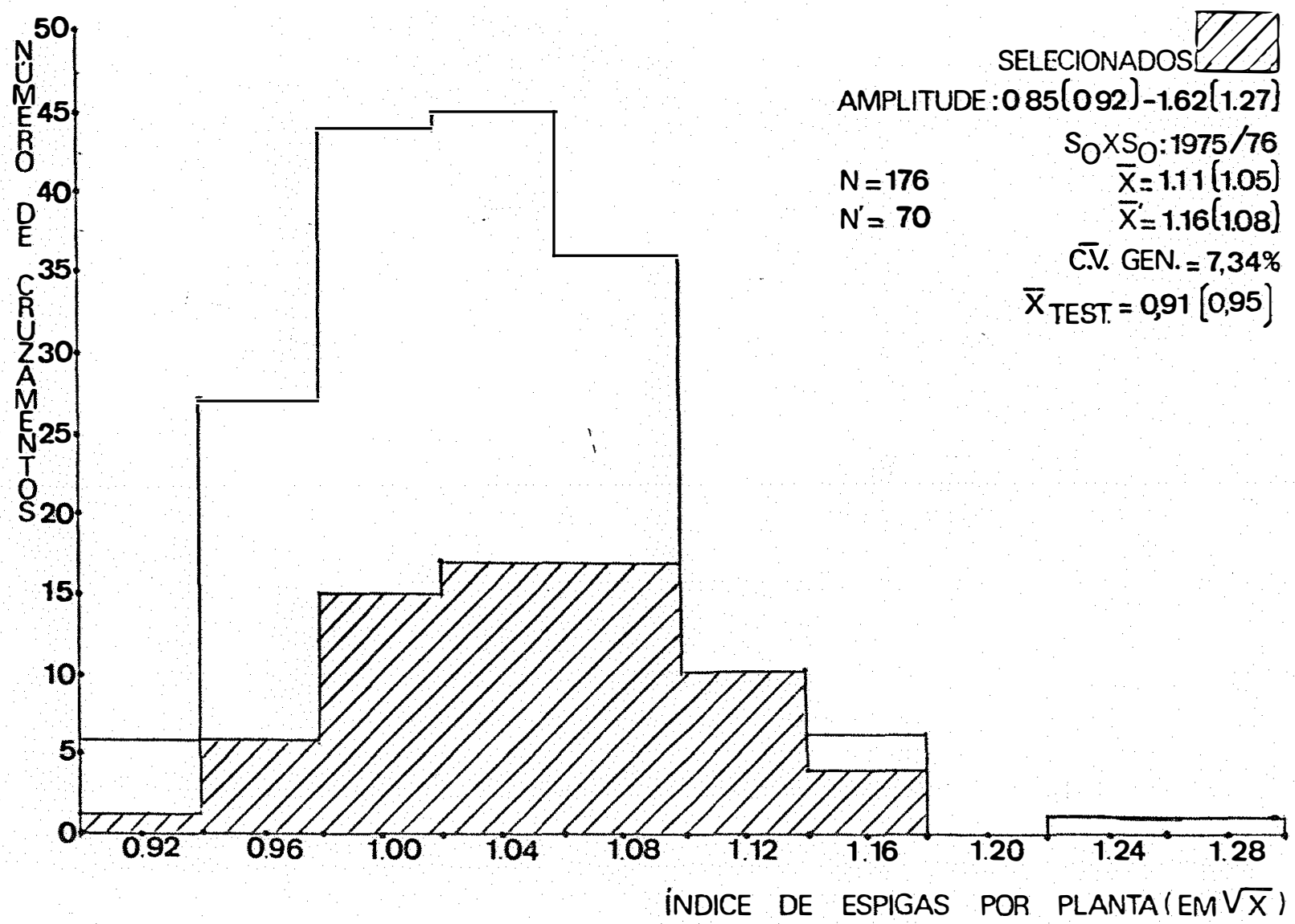

Figura 05 - Distribuição de frequências dos índices de espiga por planta dos 176 híbridos crípticos correspondentes aos três experimentos, transformados em $\sqrt{x}$. So $\times$ So. Piracicaba, 1975/76. 


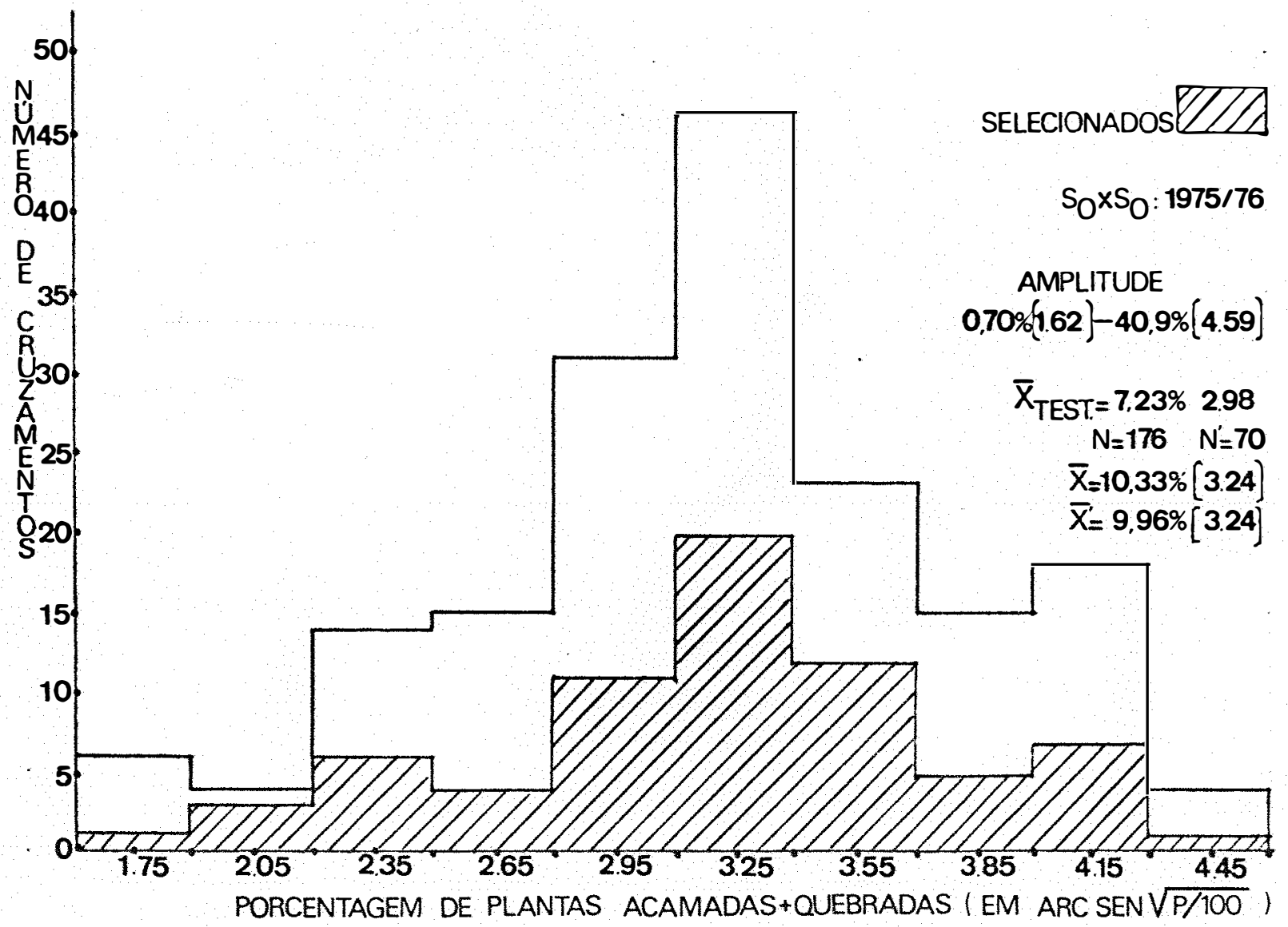

Figura 06 - Distribuição de frequência das porcentagem média de plantas acamadas (acamadas + quebradas) por tratamento $(P)$, dos $176 \mathrm{hi}$ bridos cripticos correspondentes aos três experimentos, transformados em arc sen $\sqrt{\mathrm{P} / 100} \cdot \mathrm{S}_{0} \times \mathrm{S}_{0}$. Piracicaba, 1975/76. 